\title{
Explosive Radiation of Malpighiales Supports a Mid-Cretaceous Origin of Modern Tropical Rain Forests
}

\section{Citation}

Davis, Charles C., Campbell O. Webb, Kenneth J. Wurdack, Carlos A. Jaramillo, and Michael J. Donoghue. 2005. Explosive radiation of Malpighiales supports a mid-Cretaceous origin of modern tropical rain forests. American Naturalist 165(3): E36-E65.

\section{Published Version}

http://dx.doi.org/10.1086/428296

\section{Permanent link}

http://nrs.harvard.edu/urn-3:HUL.InstRepos:2710469

\section{Terms of Use}

This article was downloaded from Harvard University's DASH repository, and is made available under the terms and conditions applicable to Other Posted Material, as set forth at http:// nrs.harvard.edu/urn-3:HUL.InstRepos:dash.current.terms-of-use\#LAA

\section{Share Your Story}

The Harvard community has made this article openly available.

Please share how this access benefits you. Submit a story.

\section{Accessibility}




\title{
Explosive Radiation of Malpighiales Supports a Mid-Cretaceous Origin of Modern Tropical Rain Forests
}

\author{
Charles C. Davis, ${ }^{1, *}$ Campbell O. Webb, ${ }^{2, \dagger}$ Kenneth J. Wurdack, ${ }^{3, \ddagger}$ Carlos A. Jaramillo, ${ }^{4, \S}$ and \\ Michael J. Donoghue ${ }^{2, \|}$
}

1. Department of Ecology and Evolutionary Biology, University of Michigan Herbarium, Ann Arbor, Michigan 48108-2287;

2. Department of Ecology and Evolutionary Biology, Yale

University, P.O. Box 208106, New Haven, Connecticut 06520;

3. Department of Botany and Laboratories of Analytical Biology, Smithsonian Institution, P.O. Box 37012, National Museum of

Natural History, MRC-166, Washington DC 20013-7012;

4. Biostratigraphy Team, Instituto Colombiano del Petróleo, AA

4185, Bucaramanga, Colombia

Submitted May 12, 2004; Accepted October 27, 2004;

Electronically published February 1, 2005

ABSTRACT: Fossil data have been interpreted as indicating that Late Cretaceous tropical forests were open and dry adapted and that modern closed-canopy rain forest did not originate until after the Cretaceous-Tertiary (K/T) boundary. However, some mid-Cretaceous leaf floras have been interpreted as rain forest. Molecular divergencetime estimates within the clade Malpighiales, which constitute a large percentage of species in the shaded, shrub, and small tree layer in tropical rain forests worldwide, provide new tests of these hypotheses. We estimate that all 28 major lineages (i.e., traditionally recognized families) within this clade originated in tropical rain forest well before the Tertiary, mostly during the Albian and Cenomanian (112-94 Ma). Their rapid rise in the mid-Cretaceous may have resulted from the origin of adaptations to survive and reproduce under a closed forest canopy. This pattern may also be paralleled by other similarly diverse lineages and supports fossil indications that closed-canopy tropical rain forests existed well before the K/T boundary. This case illustrates that dated phylogenies can provide an important new source of evidence bearing on the timing of major environmental changes, which may be especially useful when fossil evidence is limited or controversial.

\footnotetext{
* Corresponding author; e-mail: chdavis@umich.edu.

† E-mail: campbell.webb@yale.edu.

₹ E-mail: kwurdack@lms.si.edu.

s E-mail: carlos.jaramillo@ecopetrol.com.co.

"| E-mail: michael.donoghue@yale.edu.
}

Am. Nat. 2005. Vol. 165, pp. E36-E65. (c) 2005 by The University of Chicago. 0003-0147/2005/16503-40446\$15.00. All rights reserved.
Keywords: biome evolution, fossils, K/T boundary, Malpighiales, penalized likelihood, tropical rain forest.

Modern tropical rain forests are one of the most important and species rich biomes on the planet. They can be defined as having a stratified closed canopy, as receiving abundant precipitation, as experiencing equable temperatures, and as containing woody angiosperm species, at least in the understory (Richards 1996; Whitmore 1998; Morley 2000). During the past 20 years the view has become widespread that the expansion and diversification of this vegetation type occurred principally during the past 65 million years, following the mass extinction event at the CretaceousTertiary (K/T) boundary ( 65 Ma [Tiffney 1984; Wing and Boucher 1998; Morley 2000; Johnson and Ellis 2002; Ziegler et al. 2003]; Cretaceous and Cenozoic timescales following Gradstein et al. [1995] and Berggren et al. [1995]). This hypothesis was initially supported by the rarity of large stems (Wheeler and Baas 1991; Wing and Boucher 1998) and large diaspores (Tiffney 1984; Wing and Boucher 1998) of angiosperms in the Cretaceous and by the marked increase in diaspore size in the Early Tertiary. Large seeds facilitate the establishment of seedlings under a rain forest canopy (Grime 1979).

Studies of fossil leaves and wood (Upchurch and Wolfe 1987, 1993; Wolfe and Upchurch 1987) partially corroborated this pattern by indicating that most Late Cretaceous floras of southern North America, which was tropical or nearly so, represented open and subhumid (though not deciduous) forests. This contrasts with fossil floras in the same areas after the recovery from the K/T extinction event, which resemble modern tropical rain forests (Wolfe and Upchurch 1987; Johnson and Ellis 2002). However, floras from the early Late Cretaceous (Cenomanian; 100 Ma) of Kansas, Nebraska, and New Jersey have leaf sizes and morphologies characteristic of wetter climates (Wolfe and Upchurch 1987). Upchurch and Wolfe (1993) interpreted one flora (Fort Harker, KS) as typical megathermal $\left(>20^{\circ}\right.$ mean annual temperature [Upchurch and Wolfe 
1987]) rain forest and as evidence against the view that such forests did not originate until the Tertiary.

The advent of strongly supported phylogenies of living plants based primarily on molecular sequence data provides a new source of evidence on questions of this sort. Here we argue that insights into the origin of modern tropical rain forests (as defined above) can be obtained by estimating the timing of the diversification of major angiosperm clades that inhabit these forests and by demonstrating that the habitat of the ancestral species of these diversifications most likely occurred in warm, wet, closedcanopy forests. This novel approach to examining biome evolution may help to break the impasse on the question of the age of the modern tropical rain forest when direct fossil evidence is limited.

One large clade of tropical flowering plants that is especially suited for such an analysis is Malpighiales (APG 2003). Members of Malpighiales were previously assigned to 13 different angiosperm orders (Cronquist 1981) and are highly diverse in both morphology and species (Chase et al. 2002). They include $\sim 16,000$ species ( $\sim 6 \%$ of all angiosperms; numbers of species from Stevens [2003]; total angiosperm species diversity from Thorne [2002]) belonging to many well-known tropical groups and are an important component of the understory of tropical rain forests worldwide (table 1). We used Bayesian, likelihood, and parsimony methods to estimate the phylogeny and divergence times of Malpighiales from approximately 6,300 base pairs (bp) of DNA sequence data representing all three plant genomes: plastid $a t p \mathrm{~B}$ and $r b c \mathrm{~L}$, nuclear ribosomal 18S, and mitochondrial nad1B-C. Given the resulting trees and data on the ecology of all major lineages of Malpighiales, we used both parsimony and maximum likelihood to reconstruct the probable habitat occupied by the first members of this highly diverse clade.

\section{Material and Methods}

Gene Sequencing

Our data sets include 124 species representing all traditionally recognized families of Malpighiales (APG 2003); outgroup species from the closely related clades Celastrales, Oxalidales, and Huaceae (APG 2003; Soltis et al. 2003); and members of the core eudicot clades Saxifragales (Davis and Chase 2004) and Caryophyllales (Soltis et al. 2003). Seventy-seven, 32, 20, and 11 sequences were newly obtained for this study for $a t p \mathrm{~B}, r b c \mathrm{~L}, 18 \mathrm{~S}$, and $n a d 1 \mathrm{~B}-\mathrm{C}$, respectively; the remaining were obtained from GenBank. Amplification and sequencing protocols for atp $\mathrm{B}, r b c \mathrm{~L}$, 18S, and nad1B-C followed Chase et al. (2002), Hoot et al. (1995), Soltis and Soltis (1997), and Davis and Wurdack (2004), respectively. Nucleotide sequences were aligned by eye; the ends of sequences, as well as ambiguous internal regions, were trimmed from each data set to maintain complementary data between taxa. The aligned plastid, nuclear, and mitochondrial data sets included 2,825, 1,653, and $1,887 \mathrm{bp}$, respectively. Supplementary information, including data matrices and trees analyzed in this study, is available from TreeBASE (http://www.treebase.org) or the appendixes to this article.

\section{Phylogenetic Analysis}

Parsimony bootstrap percentages (Felsenstein 1985) for each clade were estimated in PAUP* version 4.0b10 (Swofford 2003) from 10,000 heuristic search replicates, tree bisection-reconnection branch swapping, MulTrees on, and simple taxon addition (saving 10 trees per replicate). Parsimony bootstrap consensus trees generated from the three data sets revealed no strongly supported $(\geq 90 \%$ bootstrap) incongruent clades between the independent

Table 1: Contemporary importance of tree species of Malpighiales and Ericales (APG 2003) in three tropical rain forests

\begin{tabular}{|c|c|c|c|c|c|c|}
\hline \multirow[b]{2}{*}{ Location } & \multicolumn{2}{|c|}{ All species } & \multicolumn{2}{|c|}{ Malpighiales } & \multicolumn{2}{|c|}{ Ericales } \\
\hline & No. spp. & No. ind. & No. spp. & No. ind. & No. spp. & No. ind. \\
\hline \multicolumn{7}{|c|}{ All trees $\geq 10 \mathrm{~cm}$ diameter at breast height: } \\
\hline Gunung Palung & 325 & 2,807 & $69(21.2)$ & $671(23.9)$ & $32(9.8)$ & $320(11.4)$ \\
\hline Dzanga-Sangha & 258 & 2,254 & $59(22.8)$ & $537(23.8)$ & $23(8.9)$ & $413(18.3)$ \\
\hline Yasuní & 1,092 & 9,184 & $107(9.7)$ & $871(9.4)$ & $100(9.1)$ & $832(9.0)$ \\
\hline \multicolumn{7}{|c|}{ Trees $\geq 10 \mathrm{~cm}$ diameter at breast height: ${ }^{\mathrm{a}}$} \\
\hline Gunung Palung & 164 & 655 & $46(28.0)$ & $250(38.1)$ & $17(10.3)$ & $114(17.4)$ \\
\hline Dzanga-Sangha & 105 & 407 & $28(26.6)$ & $135(33.1)$ & $7(6.6)$ & $90(22.1)$ \\
\hline Yasuní & 583 & 2,139 & $62(10.6)$ & $270(12.6)$ & $44(7.5)$ & $100(4.6)$ \\
\hline
\end{tabular}

Note: Gunung Palung = Gunung Palung National Park, West Kalimantan (Webb 1997; Webb and Peart 2000); Dzanga-Sangha = DzangaSangha National Park, Central African Republic (D. Harris and J. Hall, unpublished data; Hall 2003); Yasuní = Yasuní, Ecuador (Pitman et al. 2001). Figures are the sum of trees and species at a number of sample plots at each site. Percentages of species diversity and of the total number of individuals are shown in parentheses. (Some plant groups at Dzanga-Sangha have not yet been fully separated into morphotype, and the numbers here represent an underestimate of the number of species.)

a Species that were not observed to have a maximum diameter $>25 \mathrm{~cm}$ (i.e., understory trees). 
analyses of the plastid, nuclear, and mitochondrial data sets and were subsequently analyzed simultaneously with parsimony and Bayesian methods (Whitten et al. 2000; Reeves et al. 2001). Parsimony searches were performed as above, but with 100 random taxon addition replicates saving all optimal trees at each step.

To choose the optimal model of sequence evolution, we performed a series of hierarchical likelihood ratio tests (Felsenstein 1981; Huelsenbeck and Rannala 1997) using Modeltest version 3.06 (Posada and Crandall 1998). Bayesian analyses were implemented in MrBayes version 3.0b4 (Huelsenbeck and Ronquist 2001) under the GTR $+\mathrm{I}+\Gamma$ model with default priors for the rate matrix, branch lengths, gamma shape parameter, and the proportion of invariant sites. A Dirichlet distribution was used for the base frequency parameters, and an uninformative prior was used for the tree topology. Ten chains were initiated with a random starting tree and run for one million generations sampled every 1,000 generations. Following a burn-in period of 200,000 generations, trees were sampled from the posterior distribution to calculate clade posterior probabilities.

\section{Habitat Reconstruction}

To infer the ancestral habitat of Malpighiales, we optimized the habitat of major lineages of extant Malpighiales onto the Bayesian tree with the highest likelihood score and onto the 162 most parsimonious trees using parsimony and maximum likelihood as implemented in Mesquite version 1.0 (Maddison and Maddison 2003). The habitat of major lineages of extant Malpighiales was scored as a twostate character: either inhabiting warm, wet, closed-canopy forest (i.e., rain forest) or not. Habitat was either ascertained directly from floristic and monographic treatments or inferred with the aid of distributional information on rain forests in the Americas (Prance 1989a; Richards 1996), Africa (White 1983; Richards 1996), Asia (Richards 1996; Morley 2000), and Australia (Richards 1996). Malpighiales not found in tropical rain forests typically occur in savannahs or open woodland habitats in tropical latitudes. A relatively small number of clades (e.g., some Euphorbiaceae, Salicaceae, and Violaceae), however, occur in temperate zones. We scored tropical open forest and temperate-zone inhabitants as a single state, "nonwarm/wet/ closed," because our primary concern was whether Malpighiales occupied warm, wet, closed-canopy forest ancestrally. Habitat occupancy is a valid character for ancestral state reconstruction because it is directly related to intrinsic (genetically based) physiological characteristics of taxa that inhabit this biome (Webb et al. 2002). For habitat scoring see appendix B.

We performed two reconstructions to ascertain the ancestral habitat of Malpighiales: one in which habitat was scored for each family (sensu APG [2003]) and the other in which it was scored for all genera sampled in the phylogenetic analysis. The family-level scoring helped to avoid sampling bias by ensuring that habitats occupied by unsampled genera were also included. Taxa inhabiting both rain forest and open tropical/temperate habitats were coded as polymorphic. Assumptions about character weighting were evaluated under parsimony using step matrices (Maddison 1994) to explore how great a cost must be imposed on the transition from rain forest for the ancestral condition to be unambiguously open tropical/temperate (Ree and Donoghue 1998). For the likelihood reconstructions, the single fixed tree topology with the highest likelihood score from Bayesian searches was input with branch lengths and analyzed under the general Mk1 model (Lewis 2001) with the rate parameter estimated from the data. Polymorphic taxa were analyzed as either 1 or 0 , and each of these reconstructions was performed twice under the alternative state (i.e., four analyses in total).

\section{Divergence Time Estimates}

We chose the Bayesian tree from above to test for rate constancy among lineages. Branch lengths and an associated likelihood score were calculated on this tree in PAUP* under the optimal sequence model and associated parameters with, and without, a molecular clock enforced. The test statistic $2(-\ln \mathrm{L} 1-\ln \mathrm{L} 0)$ was compared to a $\chi^{2}$ distribution (with $n-2$ degrees of freedom; $n=$ number of taxa) to assess significance. A global molecular clock was rejected $(P<.05)$ for the combined data set.

The nonclock tree was rooted with Dillenia and Peridiscus, which are members of the core eudicot clades Caryophyllales (Soltis et al. 2003) and Saxifragales (Davis and Chase 2004), respectively (see app. C for full tree). Divergence times were estimated on this tree using penalized likelihood (PL; Sanderson 2002) as implemented in r8s version 1.7 (Sanderson 2003). Penalized likelihood has been shown to outperform both clock and nonclock nonparametric rate smoothing methods when data depart from a molecular clock (Sanderson 2002). This method relies on a data-driven, cross-validation procedure that sequentially removes taxa from the tree, estimates parameters without the removed branch, and calculates the $\chi^{2}$ error associated with the difference between the predicted and actual values. The optimal smoothing value for the global data set was 31.62 .

To estimate standard errors associated with divergence times, we used the parametric bootstrapping strategy outlined by Davis et al. (2002): 100 data sets were simulated on the $\mathrm{r} 8$ smoothed topology using the computer software Seq-Gen version 1.2.7 (Rambaut and Grassly 1997); re- 
sulting simulated data sets were imported into PAUP*, and branch lengths were estimated on the smoothed topology for each of these data sets with the sequence model and parameters estimated from the original data; and resulting branch length estimates from the simulated data sets were used to calculate the variance in divergence time estimates (i.e., 95\% confidence interval).

We used four macrofossils and 11 palynofossils from the Cretaceous and Tertiary as reliable minimum age constraints for several internal clades (table 2). Two maximum age constraints were independently enforced for the basal node of the tree. We first constrained the basal node to be no older than $125 \mathrm{~m}$.yr. This corresponds to the earliest known occurrence of tricolpate pollen, a synapomorphy that marks the eudicot clade, of which Malpighiales are a member (Magallón et al. 1999; Sanderson and Doyle 2001; APG 2003). The pollen fossil record has been intensively studied throughout the initial rise of angiosperms, and tricolpate pollen increases steadily in abundance and diversity from its first isolated reports in the late Barremian, becoming ubiquitous in the Albian. Hence, it has been considered unlikely that the eudicot clade originated much earlier than the late Barremian (Magallón et al. 1999; San- derson and Doyle 2001). This may be an overestimate for the age of our basal node, which does not correspond to the entire eudicot clade but rather to core eudicots exclusive of Gunnerales (Soltis et al. 2003). We also chose this date because it corresponds to the oldest molecular age estimate by Wikström et al. (2001) for our basal node (their node 12).

We also constrained the basal node to be no older than 109 m.yr., which was the youngest (and therefore the most conservative) age estimate by Wikström et al. (2001) for the same node. Our choice of this constraint was influenced in part by the fact that their youngest estimates dated the entire eudicot clade (their node 6) as 125 m.yr., which we have taken as a maximum age for eudicots based on the fossil record of tricolpate pollen (Magallón et al. 1999; Sanderson and Doyle 2001).

\section{Results}

Our phylogenetic analyses and clock-independent dating estimates indicate that all of the 28 major lineages within Malpighiales, plus the previously unplaced taxon Centroplacus (APG 2003), originated well before the K/T bound-

Table 2: Fossil age constraints

\begin{tabular}{|c|c|c|c|c|}
\hline Extant taxon & Fossil taxon & $\begin{array}{l}\text { Fossil } \\
\text { type }\end{array}$ & $\begin{array}{l}\text { Oldest reliable age } \\
\qquad(\mathrm{Ma})\end{array}$ & Location \\
\hline Acalypha ${ }^{1}$ & Acalypha type & Pollen & Early Paleocene (61.0) & China (Kiangsu) \\
\hline Austrobuxus-Dissilaria clade ${ }^{2}$ & Malvacipollis diversus & Pollen & Late Paleocene (55.5) & Australia \\
\hline Balanops ${ }^{3}$ & Balanops caledonica & Pollen & Late Oligocene (23.8) & Scotland (Hebrides) \\
\hline Caryocar ${ }^{4}$ & $\begin{array}{l}\text { Retisyncolporites } \\
\text { angularis }\end{array}$ & Pollen & Early Eocene (55.5) & Venezuela \\
\hline Casearia $^{5}$ & Casearia type & Pollen & (Late) Middle Eocene (37.0) & Panama \\
\hline Chrysobalanus $^{6}$ & Chrysobalanus type & Pollen & $\begin{array}{l}\text { (Early) Middle Eocene } \\
\quad(49.0)\end{array}$ & Colorado \\
\hline Clusiaceae $^{7}$ & Palaeoclusia chevalieri & Flower & Late Turonian (89.0) & New Jersey \\
\hline Ctenolophon ${ }^{8,9}$ & $\begin{array}{l}\text { Ctenolophonidites } \\
\text { costatus }\end{array}$ & Pollen & Maastrichtian (66.0) & Nigeria \\
\hline Cunoniaceae $^{10}$ & Platydiscus peltatus & Flower & Early Campanian (83.5) & $\begin{array}{l}\text { Sweden (Kristianstad } \\
\text { Basin) }\end{array}$ \\
\hline Drypetes $^{11}$ & Drypetes type & Pollen & Late Eocene (33.7) & France (Aisne) \\
\hline Hippomaneae (Homalanthus) $)^{12,13}$ & Crepetocarpon perkinsii & Fruit & Middle Eocene (40.0) & Tennessee \\
\hline Phyllanthus ${ }^{14}$ & Phyllanthus type & Pollen & Late Eocene (33.7) & Atlantic Ocean \\
\hline $\begin{array}{l}\text { Rhizophoraceae sensu lato } \\
\text { (incl. Erythroxylaceae) }^{15,16}\end{array}$ & Zonocostites ramonae & Pollen & (Early) Late Eocene (36.9) & Colombia \\
\hline Salix-Populus clade $e^{17}$ & Pseudosalix handleyi & $\begin{array}{l}\text { Twigs, } \\
\text { leaves, } \\
\text { flowers }\end{array}$ & Middle Eocene (48.0) & Utah \\
\hline $\begin{array}{l}\text { Stigmaphylloids (Malpighiaceae } \\
\text { crown group) }{ }^{18-20}\end{array}$ & Perisyncolporites pokornyi & Pollen & Middle Eocene (49.0) & Colombia \\
\hline
\end{tabular}

Note: Each fossil taxon provides a reliable minimum age estimate for taxa sampled in this study. In the case of palynofossils, we selected only pollen types that were easily assignable to taxa included in our phylogenetic analyses. Palynofossils assigned to extant taxa are based on taxonomic assessments by Muller (1981) and updated accordingly for taxonomy and stratigraphy following the numerical references in appendix A (which includes a tree showing fossil constraints). For Cretaceous and Cenozoic timescales see Gradstein et al. (1995) and Berggren et al. (1995). 
ary. Given our maximum age constraint of 125 m.yr. (fig. 1), Malpighiales originated in the late Aptian (114 Ma), and most major clades began to diversify shortly thereafter. The optimal age estimates for 24 of these 29 clades imply that they originated within a 20-m.yr. time window (114$94 \mathrm{Ma}$ ), between the Aptian and through the Cenomanian: five during the late Aptian (114-112 Ma), 16 during the Albian (111-100 Ma), and three during the Cenomanian (98-94 Ma). Three more clades appeared during the Coniacian $(89-85 \mathrm{Ma})$, and the two most recently derived originated during the Campanian (76 Ma).

Optimal age estimates in which the maximum age constraint for our basal node was 109 m.yr. yielded similar results: Malpighiales originated in the mid-Albian (102 $\mathrm{Ma}), 24$ of the 29 clades originated within a 13-m.yr. window (102-89 Ma) from the Albian to the Turonian, one during the Santonian (84 Ma), and four during the Campanian (78-72 Ma). These ages are more consistent with the fossil pollen record because most core eudicots have tricolpate pollen, which does not appear until within the Albian (e.g., Doyle and Robbins 1977).

All of our age estimates for crown group Malpighiales are much older than those inferred by Wikström et al. (2001; their node 22, 81-74 Ma vs. our estimates of 119$101 \mathrm{Ma})$. The conclusion that their estimates are too young holds even without the use of molecular dating methods because fossil flowers of Clusiaceae, representing a fairly derived clade within Malpighiales (perhaps related to the modern genera Clusia and Garcinia), are known from the Turonian, about $89 \mathrm{Ma}$ (Crepet and Nixon 1998).

Tropical rain forest was inferred to be the ancestral habitat for Malpighiales, and for most of the clades shown in figure 1. Under parsimony, a cost of between 2.67 and 3.01 for the Bayesian tree, and between 2.64 and 3.01 for the parsimony trees, had to be imposed on the transition from rain forest to open tropical/temperate habitats before the ancestral condition was inferred to be open tropical/ temperate. Maximum likelihood reconstructions yielded similarly robust results (table 3 ).

\section{Discussion}

As we have noted, fossil evidence indicates that tropical rain forest appeared after the $\mathrm{K} / \mathrm{T}$ event in many areas where Late Cretaceous forests were apparently more open and dry adapted (Tiffney 1984; Upchurch and Wolfe 1987, 1993; Wolfe and Upchurch 1987; Wing and Boucher 1998; Morley 2000; Johnson and Ellis 2002; Ziegler et al. 2003). Further expansion and taxonomic diversification of this biome took place during the Cenozoic. The PaleoceneEocene transition $(\sim 50 \mathrm{Ma})$ was characterized by high global temperatures (Wolfe 1978; Upchurch and Wolfe 1987; Zachos et al. 2001) and coincided with a significant increase in low-latitude palynofloral diversity (Jaramillo 2002). A similar, although less pronounced, climatic optimum during the mid-Miocene $(\sim 15 \mathrm{Ma}$; Zachos et al. 2001) resulted in the reexpansion and diversification of rain forests worldwide (Morley 2000). Finally, Quaternary (1.6-0 Ma) glacial cycles are thought to account for the diversification of many species-rich rain forest clades (Prance 1982; Whitmore and Prance 1987; Behrensmeyer et al. 1992; Richardson et al. 2001). Major geological events during the Cenozoic also facilitated the intercontinental migration of tropical plants, for example, the closing of the Tethys Seaway (Hall 1998), Paleogene land connections across the North Atlantic (Tiffney 1985a, 1985b; Davis et al. 2002a), and Neogene uplift of the Andes and the closure of the Isthmus of Panama (Gentry 1982; Burnham and Graham 1999).

Although these Cenozoic events surely contributed to the diversification of many rain forest clades, age estimates for Malpighiales suggest that its major lineages originated well before the K/T boundary. The simplest interpretation of our results is that Malpighiales occupied closed-canopy, moist, megathermal forests (i.e., rain forests) during their early evolution in the mid-Cretaceous. The alternative, that preexisting lineages in Malpighiales entered the rain forest habitat independently, would require that all the various morphological and physiological adaptations associated with living in this environment (Richards 1996; Whitmore 1998) evolved independently in most of the 29 major lineages and that all their non-rain forest ancestors went extinct. It could be that Late Cretaceous Malpighiales lived in the wettest, most shaded local habitats in open subhumid forests, as suggested by the fact that Turonian Clusiaceae, used as our oldest minimum age constraint (Crepet and Nixon 1998), are from a flora (South Amboy) thought to represent the subhumid interval (Wolfe and Upchurch 1987) and were "preadapted" to the appearance of rain forest climates. However, under this scenario we would expect to find more lines of Malpighiales persisting today in drier areas.

Limited Cretaceous fossil data (Upchurch and Wolfe 1987, 1993; Wolfe and Upchurch 1987; Morley 2000) suggest that angiosperm-dominated moist megathermal forests had arisen by the Cenomanian in the interval of the inferred origin of most rain forest clades in Malpighiales. Cenomanian leaves from the Dakota Formation of Kansas and Nebraska and the lower Raritan Formation of New Jersey (Woodbridge Clay) are physiognomically diverse and show many of the foliar adaptations characteristic of understory plants of modern tropical rain forests (Richards 1996), including large leaves with entire margins and drip tips, as well as plants with probable vining habits (Upchurch and Wolfe 1987, 1993; Wolfe and Upchurch 1987; Morley 2000). A flora from the Dakota Formation near 


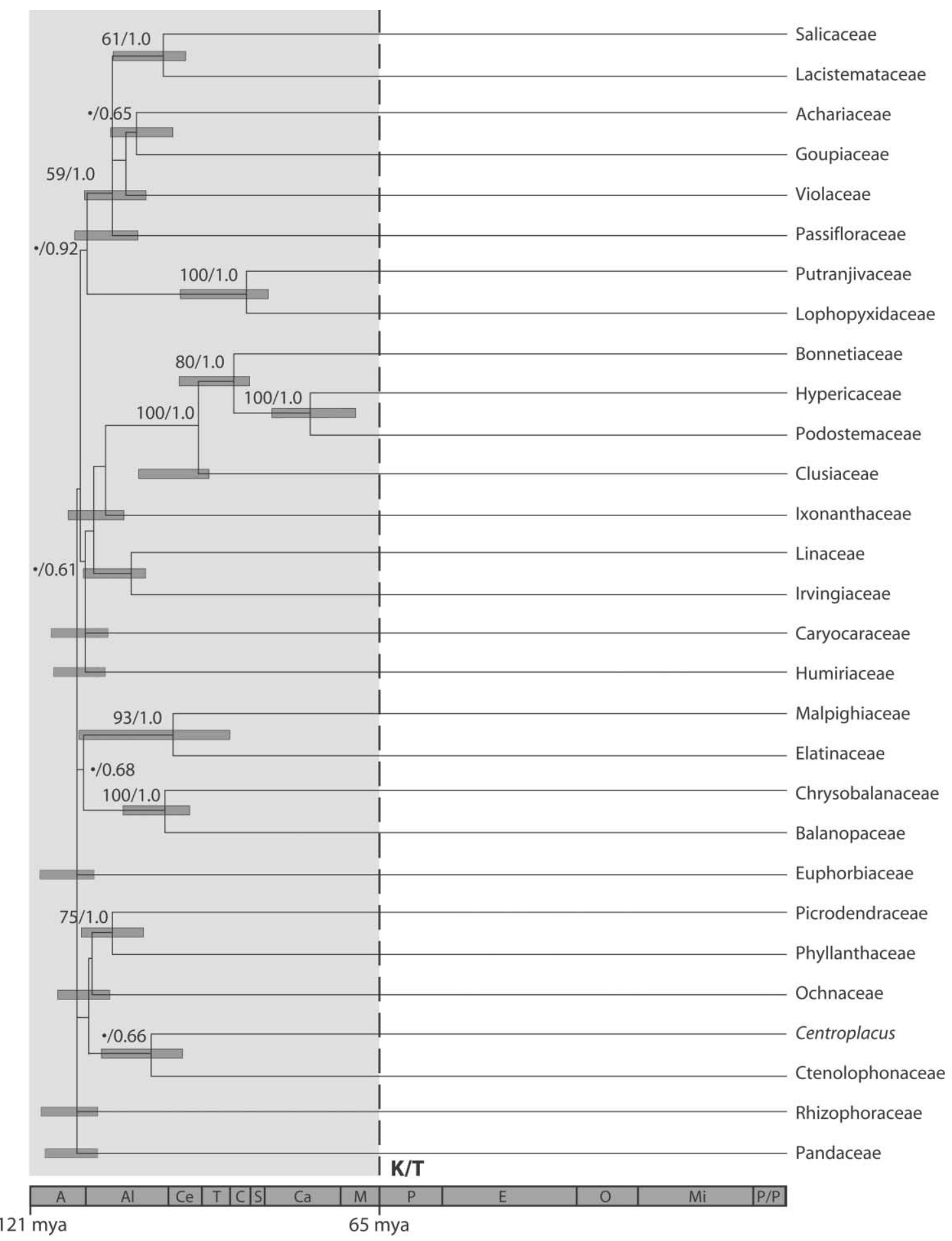

Figure 1: Penalized likelihood chronogram of Malpighiales. Figure reduced from 124-taxon data set to represent only the 28 recommended families of Malpighiales sensu APG (2003) plus the previously unplaced taxon Centroplacus. For outgroups and rooting see text. Bootstrap values and Bayesian posterior clade probabilities $(>50 \% / 0.50)$, respectively, indicated near nodes; bullet $=$ support values $\leq 50 \% / 0.50$. The monophyly of Malpighiales was supported by a very high bootstrap value (100\%) and posterior probability (1.0). Confidence intervals shown with shaded bars. Divergence times were calculated on this rate-smoothed topology by calibrating nodes with several minimum age constraints from macrofossil and palynological data (table 1). A maximum age constraint of 125 m.yr. was enforced for the root node based on the oldest occurrence of tricolpate pollen grains representing the eudicot clade (see text). The K/T boundary ( $\sim 5 \mathrm{Ma}$ ) is marked with a dashed line. The origin of Malpighiales is estimated at 114 Ma. The scale bar indicates major Cretaceous and Cenozoic intervals: $A=$ Aptian, $A l=$ Albian, $C e=$ Cenomanian, $T=$ Turonian, $C=$ Coniacian, $S=$ Santonian, $C a=$ Campanian, $M=$ Maastrichtian, $P=$ Paleocene, $E=$ Eocene,$O=$ Oligocene, $M i=$ Miocene, $P / P=$ Pliocene/Pleistocene. For complete 124-taxon chronogram, see appendix C. 
Table 3: Ancestral habitat for major Malpighiales clades illustrated in figure 1 as inferred from maximum likelihood

\begin{tabular}{|c|c|c|c|c|}
\hline \multirow[b]{2}{*}{ Taxa } & \multicolumn{2}{|c|}{$\begin{array}{c}\text { Family scoring } \\
\text { (TRF : OT/T) }\end{array}$} & \multicolumn{2}{|c|}{$\begin{array}{c}\text { Generic scoring } \\
\text { (TRF : OT/T) }\end{array}$} \\
\hline & TRF & $\mathrm{OT} / \mathrm{T}$ & TRF & $\mathrm{OT} / \mathrm{T}$ \\
\hline Achariaceae & $1.0: 0^{\mathrm{a}}$ & $.11: .89^{a}$ & $.96: .04^{\mathrm{a}}$ & $.99: .01^{\mathrm{a}}$ \\
\hline Balanopaceae & $1.0: 0^{\mathrm{a}}$ & $.99: .01^{\mathrm{a}}$ & $.92: .08^{\mathrm{a}}$ & $.98: .02^{\mathrm{a}}$ \\
\hline Bonnetiaceae & $.88: .12$ & $.30: .70$ & $61: .39$ & $.50: .50$ \\
\hline Caryocaraceae & $1.0: 0^{\mathrm{a}}$ & $.96: .04^{a}$ & $.98: .02^{\mathrm{a}}$ & $1.0: 0^{\mathrm{a}}$ \\
\hline Centroplacus & $1.0: 0^{\mathrm{a}}$ & $.93: .07^{a}$ & $.97: .03^{a}$ & $.98: .02^{\mathrm{a}}$ \\
\hline Chrys & $1.0: 0^{\mathrm{a}}$ & $.99: .01^{\mathrm{a}}$ & $.92: .08^{a}$ & $.99: .01^{\mathrm{a}}$ \\
\hline Clusiaceae & $.91: .09^{a}$ & $.78: .22$ & $.75: .25$ & $.75: .25$ \\
\hline Ctenolophon & $1.0: 0^{\mathrm{a}}$ & $.93: .07^{\mathrm{a}}$ & $.97: .03^{\mathrm{a}}$ & $.99: .01^{a}$ \\
\hline Elat & $1.0: 0^{\mathrm{a}}$ & $.56: .44$ & $.87: .13$ & $.78: .22$ \\
\hline rbiaceae & $1.0: 0^{\mathrm{a}}$ & $.85: .15$ & $.99: .01^{\mathrm{a}}$ & $1.0: 0^{\mathrm{a}}$ \\
\hline Gou & $1.0: 0^{\mathrm{a}}$ & $.11: .89^{a}$ & $.96: .04^{\mathrm{a}}$ & $.99: .01^{\mathrm{a}}$ \\
\hline Hum & $1.0: 0^{\mathrm{a}}$ & $.96: .04^{a}$ & $.98: .02^{\mathrm{a}}$ & $1.0: 0^{\mathrm{a}}$ \\
\hline Нyp & $.01: .99^{a}$ & $.11: .89^{a}$ & $.69: .31$ & $.38: .62$ \\
\hline Irvin & $1.0: 0^{\mathrm{a}}$ & $.95: .05^{\mathrm{a}}$ & $.93: .07^{\mathrm{a}}$ & $.98: .02^{a}$ \\
\hline Ixol & $1.0: 0^{\mathrm{a}}$ & $.96: .04^{\mathrm{a}}$ & $.95: .05^{\mathrm{a}}$ & $.98: .02^{\mathrm{a}}$ \\
\hline Lacis & $1.0: 0^{\mathrm{a}}$ & $.11: .89^{a}$ & $.91: .09^{\mathrm{a}}$ & $.82: .18$ \\
\hline Lina & $1.0: 0$ & $.95: .05^{\mathrm{a}}$ & $.93: .07^{\mathrm{a}}$ & $.98: .02^{\mathrm{a}}$ \\
\hline Loph & $1.0: 0^{\mathrm{a}}$ & $.94: .06^{\mathrm{a}}$ & $.84: .16$ & $.91: .09^{\mathrm{a}}$ \\
\hline Mal & $1.0: 0^{\mathrm{a}}$ & $.56: .44$ & $.87: .13$ & $.78: .22$ \\
\hline Malpi & $1.0: 0^{\mathrm{a}}$ & $.86: .14$ & $.99: .01^{\mathrm{a}}$ & $1.0: 0^{\mathrm{a}}$ \\
\hline Ochnaceae & $1.0: 0^{\mathrm{a}}$ & $.78: .22$ & $.97: .03^{\mathrm{a}}$ & $.99: .01^{\mathrm{a}}$ \\
\hline Pandaceae & $1.0: 0^{\mathrm{a}}$ & $.92: .08^{\mathrm{a}}$ & $.99: .01^{\mathrm{a}}$ & $.99: .01^{\mathrm{a}}$ \\
\hline Passifloraceae & $1.0: 0^{\mathrm{a}}$ & $.12: .88^{a}$ & $.96: .04^{\mathrm{a}}$ & $.98: .02^{\mathrm{a}}$ \\
\hline Phyllanthaceae & $1.0: 0^{\mathrm{a}}$ & $.22: .78$ & $.94: .06^{\mathrm{a}}$ & $.96: .04^{\mathrm{a}}$ \\
\hline Picrodendracea & $1.0: 0^{\mathrm{a}}$ & $.22: .78$ & $.94: .06^{\mathrm{a}}$ & $.96: .04^{\mathrm{a}}$ \\
\hline Podostemaceae & $.01: .99^{a}$ & $.11: .89^{a}$ & $.69: .31$ & $.38: .62$ \\
\hline Putranjivaceae & $1.0: 0^{\mathrm{a}}$ & $.94: .06^{\mathrm{a}}$ & $.84: .16$ & $.91: .09^{\mathrm{a}}$ \\
\hline Rhizophorac & $1.0: 0^{\mathrm{a}}$ & $.92: .08^{a}$ & $.99: .01^{a}$ & $1.0: 0^{\mathrm{a}}$ \\
\hline Salicaceae & $1.0: 0^{\mathrm{a}}$ & $.11: .89^{a}$ & $.91: .09^{\mathrm{a}}$ & $.82: .18$ \\
\hline Violaceae & $1.0: 0^{\mathrm{a}}$ & $.11: .89^{a}$ & $.96: .04^{\mathrm{a}}$ & $.98: .02^{\mathrm{a}}$ \\
\hline
\end{tabular}

Note: Proportional likelihood values of rain forest habitat (TRF) versus those in open tropical/temperate environments (OT/T) are separated by a colon. Reconstructions for both familial and generic scorings are shown and are further subdivided into analyses in which all taxa that had been scored as polymorphic were coded as either TRF or OT/T. Boldface indicates stem groups for which there is significant statistical support for OT/T environments. Stem clade reconstructions are shown unless otherwise indicated as CG (crown group).

${ }^{a}$ Reconstruction judged best as determined by a log-likelihood decline of at least two units between states (i.e., the threshold value).

Fort Harker, Kansas, contains especially large leaves and was cited (Upchurch and Wolfe 1987, 1993; Wolfe and Upchurch 1987) as evidence that typical rain forest originated much earlier than others have argued. This inferred period of wetter climates is also supported by paleoclimatic reconstructions for the Cenomanian (Barron and Washington 1985; Barron et al. 1989; Beerling and Woodward 2001), which indicate that mid latitudes may have been similar in precipitation and temperature to present-day low latitudes. Moreover, vegetation simulations for the mid-Cretaceous suggest that rain forests could have existed in low-latitude regions of present-day South America, Africa, northern Australia, and India (Beerling and Woodward 2001), and they may have persisted in similar areas until the latest Cretaceous (Otto-Bliesner and Upchurch 1997; Upchurch et al. 1998; Beerling and Woodward 2001).

Extraordinary fossil evidence from the Castle Rock flora of Colorado suggests that highly diverse rain forests were present in North America shortly after the K/T boundary (Johnson and Ellis 2002). Johnson and Ellis (2002) interpreted these forests as a new phenomenon of the Cenozoic, but our phylogenetic evidence from Malpighiales, ancillary evidence from Cenomanian floras such as Fort Harker, and paleoclimate models suggest instead that on a global scale, rain forests may be much older. Any Cretaceous rain forests, however, must have been more geographically restricted than those that developed during the Cenozoic. Although tropical floras are well known at middle latitudes in the Late Cretaceous, most of them indicate subhumid conditions. However, this does not rule out the existence of wet megathermal vegetation at lower latitudes, where there are numerous fossil pollen floras but megafossil floras, which allow more direct inferences on physiognomy of the vegetation, are rare and poorly known (Upchurch and Wolfe 1987).

The rarity of large angiosperm diaspores during the Cretaceous and their increased size after the K/T boundary have also been cited as evidence that closed-canopy environments like those of modern rain forests were not present during the Cretaceous (Tiffney 1984; Wing and Boucher 1998). This assumed that larger diaspores help seedlings become established and survive better in heavily shaded environments such as the understory of tropical rain forests. Recent studies (Grubb 1996, 1998; Grubb and Metcalfe 1996), however, suggest that large diaspores, while an advantage in low-light environments, are not a requirement for successful germination and establishment in the rain forest and may relate more to the ability to germinate on dense leaf litter than to light availability (see also Feild et al. 2004). Seeds of contemporary Malpighiales are on average larger than the mean for samples of all angiosperms (A. Moles, personal communication, Seed Information Database, Kew Gardens). However, the clusiaceous fossil flower from the Turonian of New Jersey was small, with a multiovulate ovary $<1 \mathrm{~mm}$ in diameter (Crepet and Nixon 1998). It is possible that the paucity of large Cretaceous diaspores is partly a function of poor sampling of low-latitude floras. Large fruits and seeds from the Campanian-Maastrichtian of West Africa were the main exception noted by Wing and Tiffney (1987) to their generalization that Cretaceous angiosperm diaspores were small (cf. Chesters 1955). Another possibility is that the 
small size of Cretaceous diaspores reflects not so much open environments as the absence of bird and mammal dispersers, whose radiation after the K/T event has been proposed as an alternative explanation for the Early Tertiary increase in diaspore size (Wing and Tiffney 1987).

Malpighiales account for up to $40 \%$ of the understory tree community in tropical rain forests (table 1). We suggest that Malpighiales were among the earliest angiosperm colonizers of the understory in the Cretaceous (Crane 1987), following representatives of the basal ANITA grade, which have been depicted as playing a similar role at the earliest stages of the angiosperm radiation (Feild et al. 2004). ANITA-grade plants, some eumagnoliids, and Malpighiales may have successfully competed with existing nonangiospermous plants in the understory, and Malpighiales may have filled a niche that was less occupied by the other new angiosperm groups: the small, subcanopy tree. Modern Malpighiales are often $2-10 \mathrm{~m}$ tall, are able to grow and reproduce without direct sunlight, and are more flexible in growth habit than cycad-like seed plants (Crane 1987; Feild et al. 2004), that is, like ANITA-grade plants but generally taller. The recently documented (Schneider et al. 2004) Late Cretaceous radiation of derived ferns (Polypodiaceae sensu lato) may represent a parallel occupation of forest floor and epiphytic niches.

Most angiosperm wood fossils from the mid-Cretaceous are relatively small (Crane 1987; Wing and Boucher 1998), suggesting that the forest canopy at the beginning of the radiation of Malpighiales was dominated by large conifers (Crane 1987). The diversity of conifers remained relatively steady during the late Albian-early Cenomanian, whereas cycadophytes, pteridophytes, and pteridosperms exhibited dramatic declines. Crane (1987) suggested that the latter taxa were replaced by angiosperm shrubs or small trees. A similar mixture of dicotyledonous trees and conifers is found today in the heath and montane forests of southeast Asia, which contain emergent Agathis or Dacrydium species, and the giant Araucaria- and Agathis-dominated rain forests of Queensland, New Guinea, New Caledonia, and New Zealand (Richards 1996). By the time of the Cenomanian Dakota and Raritan floras, however, the shift in the dominant trees from conifers to angiosperms had probably occurred (Upchurch and Wolfe 1987, 1993; Wolfe and Upchurch 1987; Cantrill and Poole 2005).

The pattern exhibited by Malpighiales may be paralleled by other similarly diverse tropical clades. Ericales (APG 2003), for example, form a well-supported clade (Bremer et al. 2002) and are morphologically heterogeneous; their members have been placed in 11 different angiosperm orders (Cronquist 1981), and they are similarly species rich ( 11,000 species; see Stevens 2003 and Thorne 2002). Ericales also form an important component of the understory diversity in tropical rain forests (up to $22 \%$; table 1). Together, Ericales and Malpighiales account for more than half of the understory stems in some of these forests ( $\sim 55 \%$ in Asia and Africa). Molecular divergence-time estimates for Ericales suggest that they originated in the Cretaceous during approximately the same time period as Malpighiales ( 106 Ma [Wikström et al. 2001]). Like Malpighiales, Ericales have a fossil record dating back to the Turonian (Magallón et al. 1999), and it appears that many of their major lineages may extend back to the Cretaceous (Bremer et al. 2002) and originated rapidly (Anderberg et al. 2002). The coincident pattern of diversification in these two major clades may mark the origin of tropical rain forests as we know them today. In the case of Malpighiales, we have demonstrated that dated phylogenies can provide an important new source of evidence on the timing of major environmental changes, which may be especially useful in such cases where direct fossil evidence is limited or controversial.

\section{Acknowledgments}

We thank W. Anderson, P. Ashton, R. Burnham, J. Doyle, B. O'Meara, J. Rest, M. Sanderson, G. Upchurch, S. Wing, and M. Wojciechowski for helpful discussion; J. Hall, D. Harris, and N. Pitman for sharing forest plot data; A. Moles and the Kew Seed Information Database for seed size data; D. Mindell and P. Tucker for lab space; and M. Alford, M. Chase, and M. Simmons for DNA samples. C.C.D. was supported by the National Science Foundation (NSF) Assembling the Tree of Life grant (EF 04-31242), by a Rackham faculty grant from the University of Michigan, and by the Michigan Society of Fellows. C.O.W. was funded by the NSF (DEB-0212873). K.J.W. was supported by the Smithsonian Institution and the Lewis B. and Dorothy Cullman Program for Molecular Systematic Studies at the New York Botanical Garden. This article is dedicated to A. H. Gentry.

\section{APPENDIX A}

Numbered references for fossil minimum age constraints presented in table 2 and figure A1. Exact placement of fossil constraints are shown in figure Al using the same numbered references. Palynofossils assigned to extant taxa sampled in our data set were based on taxonomic assessments by Muller (1981) and updated accordingly for taxonomy and stratigraphy using the references below. Maximum age constraints of 125 and $109 \mathrm{Ma}$ assigned to the basal node from Magallón et al. (1999) and Wikström et al. (2001), respectively. 


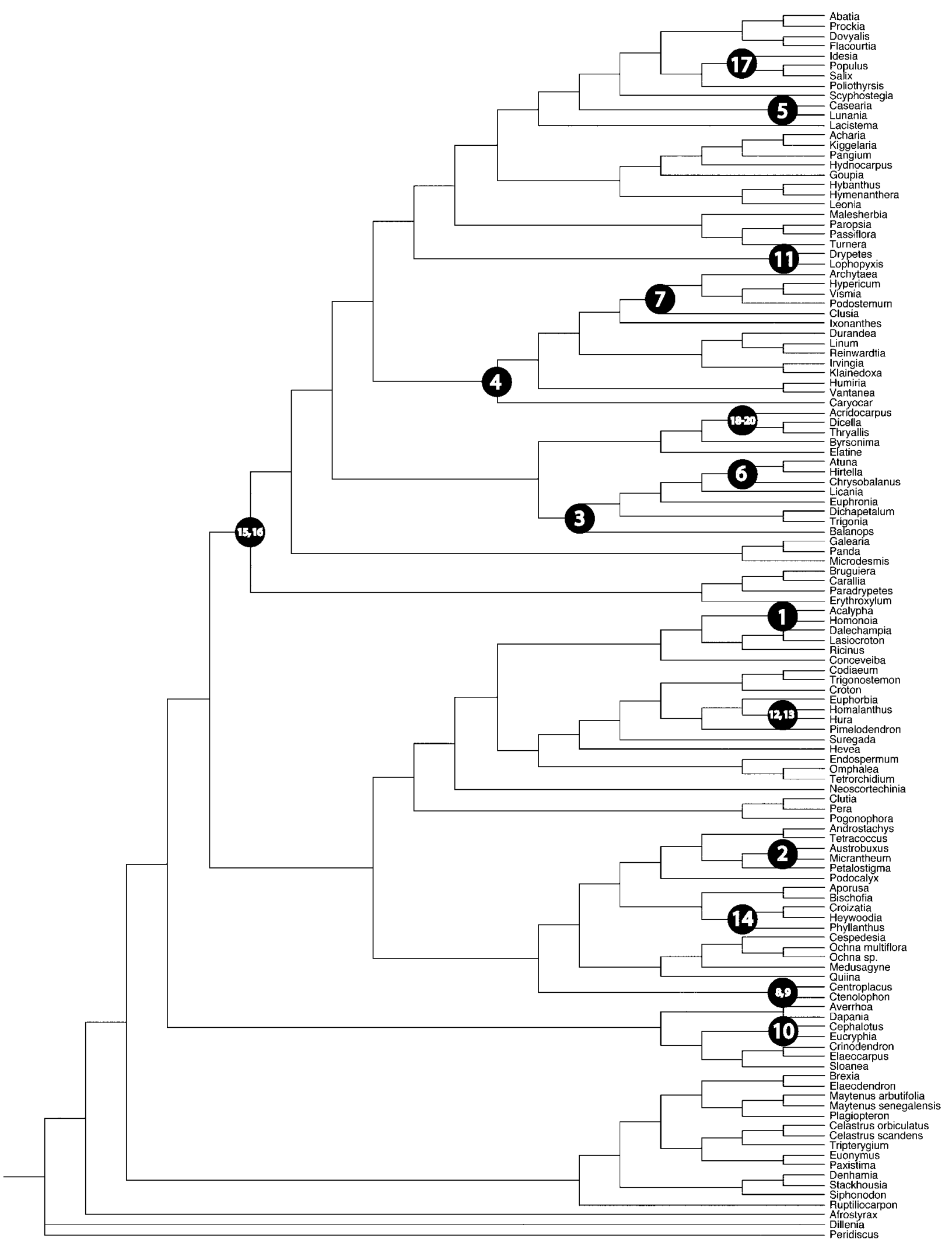

Figure A1: Fossil constraints; minimum age fossil constraints shown on tree using numbered references in appendix A 
Literature Cited in Table 2 and Figure A1

1. Sun, M., X. Sun, Y. Zhao, O. Wang, Z. Li, Z. Hu, and P. Mei. 1989. Sporo-pollen. Pages 6-111 in Division of Comprehensive Studies on Ocean Geology of the Ministry of Geology and Minerals of P. R. China and Institute of Geology of the Chinese Academy of Geological Sciences, ed. Cenozoic paleobiota of the continental shelf of East China Sea (Donghai) (Micropaleobotanical Volume). Geological Publishing House, Beijing.

2. Martin, H. A. 1981. Changing Cenozoic barriers and the Australian paleobotanical record. Annals of the Missouri Botanical Garden 69:625-667.

3. Simpson, J. B. 1961. The Tertiary pollen-flora of Mull and Ardnamurchan. Transactions of the Royal Society of Edinburgh Earth Sciences 64:421-468.

4. Rull, V. 2000. Ecostratigraphic study of Paleocene and Early Eocene palynological cyclicity in northern South America. Palaios 15:14-24.

5. Graham, A. 1985. Studies in neotropical paleobotany. IV. The Eocene communities of Panama. Annals of the Missouri Botanical Garden 72:504-534.

6. Wodehouse, R. P. 1932. Tertiary pollen. I. Pollen of the living representatives of the Green River flora. Bulletin of the Torrey Botanical Club 59:313-340.

7. Crepet, W. L., and K. C. Nixon. 1998. Fossil Clusiaceae from the Late Cretaceous (Turonian) of New Jersey and implications regarding the history of bee pollination. American Journal of Botany 85:1122-1133.

8. Edet, J. J., and E. E. Nyong. 1994. Palynostratigraphy of Nkporo Shale exposures (late Campanian-Maastrichtian) on the Calabar Flank, SE Nigeria. Review of Palaeobotany and Palynology 80:131-147.

9. Schrank, E. 1994. Palynology of the Yesomma Formation in northern Somalia: a systematic study of pollen, spores and associated phytoplankton from the Late Cretaceous Palmae Province. Palaeontographica Abteiling B Paläophytologie 231:63-112.

10. Schönenberger, J., E. M. Friis, M. L. Matthews, and P. K. Endress. 2001. Cunoniaceae in the Cretaceous of Europe: evidence from fossil flowers. Annals of Botany 88:423-437.

11. Gruas-Cavagnetto, C., and P. Anadón. 1995. Une mangrove complexe dans le Bartonien du Bassin de l'Ebre (NE de l'Espagne). Palaeontographica Abteiling B Paläophytologie 236:147-165.

12. Dilcher, D. L., and S. R. Manchester. 1988. Investigations of angiosperms from the Eocene of North America: a fruit belonging to the Euphorbiaceae. Tertiary Research 9:45-58.

13. Potter, F. W., Jr., and D. L. Dilcher. 1980. Biostratigraphic analysis of Eocene clay deposits in Henry County, Tennessee. Pages 211-225 in D. L. Dilcher and T. N. Taylor, eds. Biostratigraphy of fossil plants. Dowden, Hutchinson \& Ross, Stroudsburg, PA.

14. Zaklinskaya, E. D. 1978. Palynology of Paleogene Clay from DSDP Site 368, Cape Verde Rise. Deep Sea Drilling Project (U.S. Government Printing Office) 41:933-937.

15. Jaramillo, C. A. 2002. Response of tropical vegetation to Paleogene warming. Paleobiology 28:222-243.

16. Muller, J., E. Di Giacomo, and A. Van Erve. 1987. A palynological zonation for the Cretaceous, Tertiary, and Quaternary of northern South America. AASP Contributions Series 19:7-76.

17. Boucher, L. D., S. R. Manchester, and W. S. Judd. 2003. An extinct genus of Salicaceae based on twigs with attached flowers, fruits, and foliage from the Eocene Green River Formation of Utah and Colorado, USA. American Journal of Botany 90:1389-1399.

18. Jaramillo, C. A., and D. L. Dilcher. 2001. Middle Paleogene palynology of central Colombia, South America: a study of pollen and spores from tropical latitudes. Palaeontographica Abteiling B Paläophytologie 285:87-213.

19. Davis, C. C., W. R. Anderson, and M. J. Donoghue. 2001. Phylogeny of Malpighiaceae: evidence from chloroplast $n d h F$ and trnL-F nucleotide sequences. American Journal of Botany 88:1830-1846.

20. Davis, C. C., P. W. Fritsch, C. D. Bell, and S. Mathews. 2004. High-latitude Tertiary migrations of an exclusively tropical clade: evidence from Malpighiaceae. International Journal of Plant Sciences 165(suppl.):S107-S121. 


\section{APPENDIX B}

Table B1: Taxa sequenced, voucher information, and GenBank accession numbers

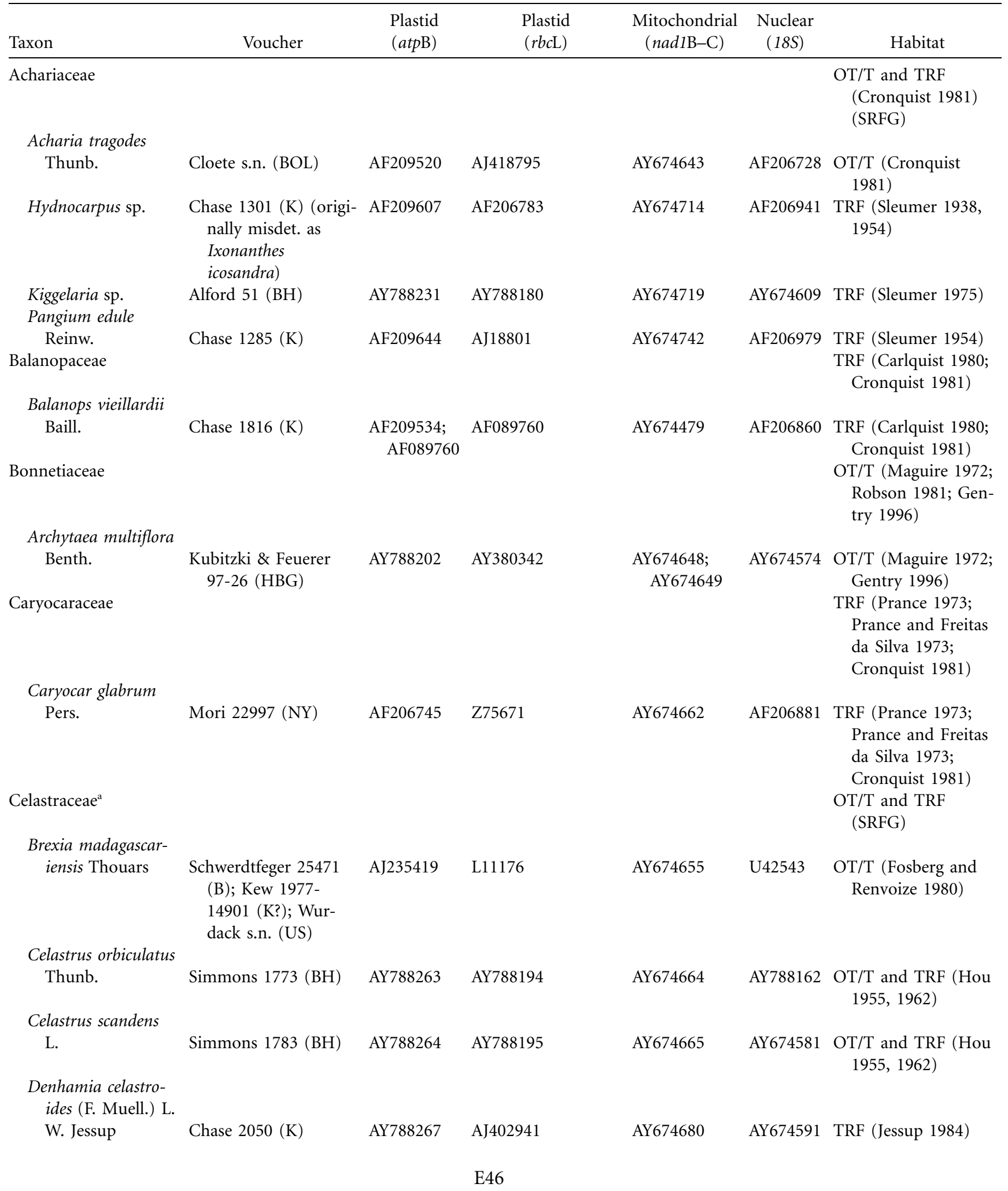


Table B1 (Continued)

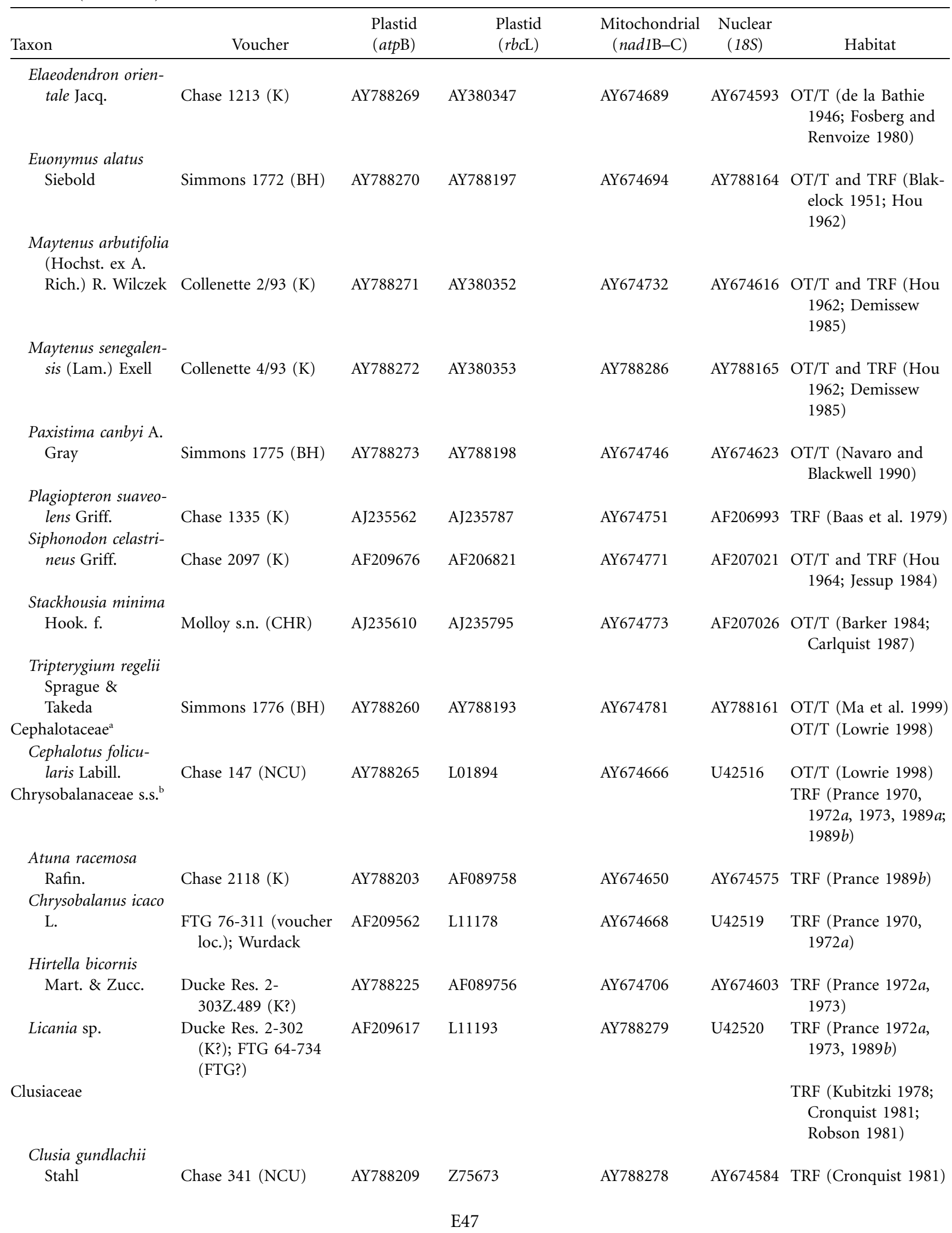


Table B1 (Continued)

\begin{tabular}{|c|c|c|c|c|c|c|}
\hline Taxon & Voucher & $\begin{array}{l}\text { Plastid } \\
(\operatorname{atp} \mathrm{B})\end{array}$ & $\begin{array}{c}\text { Plastid } \\
(r b c \mathrm{~L})\end{array}$ & $\begin{array}{l}\text { Mitochondrial } \\
(\text { nad } 1 \mathrm{~B}-\mathrm{C})\end{array}$ & $\begin{array}{l}\text { Nuclear } \\
(18 S)\end{array}$ & Habitat \\
\hline Ctenolophonaceae & & & & & & $\begin{array}{c}\text { TRF (Van Hooren and } \\
\text { Nooteboom 1988a) }\end{array}$ \\
\hline $\begin{array}{l}\text { Ctenolophon engleri- } \\
\text { anus Mildbr. }\end{array}$ & $\begin{array}{l}\text { Dourse } 1572(\mathrm{~K}) \text {; Mc- } \\
\text { Pherson } 16911 \\
\quad(\mathrm{MO})\end{array}$ & AY788215 & AJ402940 & AY674676 & AY674589 & $\begin{array}{c}\text { TRF (Van Hooren and } \\
\text { Nooteboom 1988a) }\end{array}$ \\
\hline Cunoniaceae $^{\mathrm{a}}$ & & & & & & $\begin{array}{l}\text { OT/T and TRF } \\
\text { (Hoogland 1979, } \\
\text { 1981; Bradford } \\
\text { 1998, 2002) }\end{array}$ \\
\hline Eucryphia sp. & $\begin{array}{l}\text { Strybing Arb 86-0250; } \\
\text { Chase } 2528(\mathrm{~K})\end{array}$ & AF209584 & L01918 & AY674693 & U42533 & $\begin{array}{l}\text { OT/T (Bentham and } \\
\text { Mueller 1864) }\end{array}$ \\
\hline Dichapetalaceae & & & & & & $\begin{array}{l}\text { TRF (Prance 1972b, } \\
\text { 1973; Breteler 1991) }\end{array}$ \\
\hline Dichapetalum spp. & $\begin{array}{l}\text { Fisson s.n. (K); Chase } \\
\quad 624(\mathrm{~K})\end{array}$ & AJ235455 & AF089764 & AY674683 & AF206902 & $\begin{array}{l}\text { TRF (Prance 1972b, } \\
\text { 1973; Breteler 1991) }\end{array}$ \\
\hline Dilleniaceae $^{\mathrm{a}}$ & & & & & & $\begin{array}{l}\text { TRF (Hoogland 1951, } \\
\text { 1952) }\end{array}$ \\
\hline \multicolumn{7}{|l|}{ Dillenia philippine- } \\
\hline Elaeocarpaceae $^{\mathrm{a}}$ & & & & & & $\begin{array}{l}\text { OT/T and TRF (Bri- } \\
\text { zicky 1965; Baker et } \\
\text { al. 1998) }\end{array}$ \\
\hline $\begin{array}{l}\text { Crinodendron hook- } \\
\text { erianum Gay }\end{array}$ & Chase 909 (K?) & AF209570 & AF206754 & AY674673 & AF206893 & $\begin{array}{l}\text { OT/T and TRF } \\
\text { (Bricker 1991) }\end{array}$ \\
\hline Elaeocarpus spp. & $\begin{array}{l}\text { D. M. Hicks } 8455 \\
\text { (K?); Alverson s.n. } \\
\text { (WIS) }\end{array}$ & AF209581 & AF20675 & AY788285 & AF206906 & $\begin{array}{l}\text { TRF (Baker et al. } \\
\text { 1998; Coode 2001) }\end{array}$ \\
\hline Sloanea spp. & $\begin{array}{l}\text { Alverson } 2211 \text { (WIS); } \\
\text { Chase } 343(\mathrm{NCU})\end{array}$ & AJ235603 & AF022131 & AY674772 & U42826 & $\begin{array}{l}\text { TRF (Smith 1944, } \\
\text { 1954) }\end{array}$ \\
\hline Elatinaceae & & & & & & $\begin{array}{l}\text { OT/T (Tucker 1986; } \\
\text { Leach 1989) }\end{array}$ \\
\hline $\begin{array}{l}\text { Elatine triandra } \\
\text { Schkuhr }\end{array}$ & $\begin{array}{c}\text { Brunton et al. } 13384 \\
\text { (MICH); Crins \& } \\
\text { Stabb } 9600(\mathrm{MICH})\end{array}$ & AY788219 & AY380349 & AY674690 & AY674594 & OT/T (Tucker 1986) \\
\hline Erythroxylaceae & & & & & & $\begin{array}{l}\text { OT/T and TRF } \\
\text { (Cronquist 1981) } \\
\text { (SRFG) }\end{array}$ \\
\hline Erythroxylum spp. & $\begin{array}{c}\text { FTG63-251E; Chase } \\
134 \text { (NCU?); Wur- } \\
\text { dack D713 (US) }\end{array}$ & AJ235466 & L13183 & AY674692 & AF206909 & $\begin{array}{l}\text { OT/T and TRF (de la } \\
\text { Bathie 1952; Payens } \\
\text { 1958; Cronquist } \\
\text { 1981; Verdcourt } \\
\text { 1984; Plowman } \\
\text { 1989; Webster } \\
\text { 1994b; Plowman } \\
\text { and Berry 1999) }\end{array}$ \\
\hline
\end{tabular}


Table B1 (Continued)

\begin{tabular}{|c|c|c|c|c|c|c|}
\hline Taxon & Voucher & $\begin{array}{l}\text { Plastid } \\
(\operatorname{atpB})\end{array}$ & $\begin{array}{c}\text { Plastid } \\
(r b c \mathrm{~L})\end{array}$ & $\begin{array}{l}\text { Mitochondrial } \\
(\text { nad1B-C) }\end{array}$ & $\begin{array}{c}\text { Nuclear } \\
(18 S)\end{array}$ & Habitat \\
\hline Euphorbiaceae & & & & & & $\begin{array}{l}\text { OT/T and TRF } \\
\text { (Cronquist 1981; } \\
\text { Webster 1994a; } \\
\text { 1994b) (SRFG) }\end{array}$ \\
\hline \multicolumn{7}{|l|}{ Acalypha californica } \\
\hline Benth. & Levin 2192 (SD) & AY788199 & AY380341 & AY674642 & AY674571 & $\begin{array}{l}\text { OT/T and TRF (Web- } \\
\text { ster 1994b) }\end{array}$ \\
\hline Clutia tomentosa $\mathrm{L}$. & $\begin{array}{l}\text { Geumshuizan } 6505 \\
\text { (MO) }\end{array}$ & AY788210 & AY788168 & AY674669 & AY674585 & $\begin{array}{l}\text { OT/T (Webster 1994a, } \\
\text { 1994b) }\end{array}$ \\
\hline $\begin{array}{l}\text { Codiaeum variega- } \\
\text { tum (L.) Blume }\end{array}$ & Wurdack D33 (US) & AY788211 & AY788169 & AY674670 & AY674586 & $\begin{array}{l}\text { TRF (Airy Shaw } \\
\text { 1980a; Radcliffe- } \\
\text { Smith 1987; Web- } \\
\text { ster 1994b) }\end{array}$ \\
\hline $\begin{array}{l}\text { Conceveiba marti- } \\
\text { ana Baill. }\end{array}$ & Bell 93-176 (US) & AY788212 & AY788170 & AY674671 & AY674587 & $\begin{array}{l}\text { TRF (Webster 1994b; } \\
\quad \text { Murillo 2000) }\end{array}$ \\
\hline \multicolumn{7}{|l|}{$\begin{array}{l}\text { Croton alabamensis } \\
\text { var. alabamensis }\end{array}$} \\
\hline Chapman & Wurdack D8 (US) & AY788214 & AY788171 & AY674675 & AY674588 & $\begin{array}{l}\text { OT/T (Webster 1993, } \\
\text { 1994b) }\end{array}$ \\
\hline $\begin{array}{l}\text { Dalechampia spa- } \\
\text { thulata } \\
\text { (Scheidw.) Baill. }\end{array}$ & Wurdack D10 (US) & AY788216 & AY788172 & AY674677 & AY788149 & $\begin{array}{l}\text { OT/T and TRF (Web- } \\
\text { ster and Armbrus- } \\
\text { ter 1991; Webster } \\
\text { 1994b) }\end{array}$ \\
\hline $\begin{array}{l}\text { Endospermum mol- } \\
\text { uccanum (Teijsm. } \\
\text { \& Binn.) Kurz }\end{array}$ & Chase $1258(\mathrm{~K})$ & AY788220 & AJ402950 & AY674691 & AY674595 & $\begin{array}{l}\text { TRF (Airy Shaw 1972; } \\
\text { Webster 1994b) }\end{array}$ \\
\hline Euphorbia spp. & $\begin{array}{l}\text { Chase } 102(\mathrm{NCU}) ; \\
\text { voucher unknown } \\
\text { for U42535 }\end{array}$ & AJ235472 & AY788174 & AY674695 & U42535 & $\begin{array}{l}\text { OT/T and TRF (Web- } \\
\text { ster 1994b) }\end{array}$ \\
\hline Hevea sp. & Gillespie 4272 (US) & AY788223 & AY788175 & AY674703 & AY674601 & $\begin{array}{l}\text { TRF (Schultes 1990; } \\
\text { Webster 1994b) }\end{array}$ \\
\hline \multicolumn{7}{|l|}{$\begin{array}{l}\text { Homalanthus popul- } \\
\text { neus (Geiseler) }\end{array}$} \\
\hline Pax & Chase $1266(\mathrm{~K})$ & AY788226 & AY380350 & AY674707 & AY674604 & $\begin{array}{l}\text { TRF (Airy Shaw 1968; } \\
\text { Webster 1994b) }\end{array}$ \\
\hline Hura crepitans L. & Wurdack D89 (US) & AY788228 & AY788177 & AY674711 & AY674606 & $\begin{array}{l}\text { OT/T and TRF (Stan- } \\
\text { dley and Steyer- } \\
\text { mark 1949; Webster } \\
\text { 1994b) }\end{array}$ \\
\hline $\begin{array}{l}\text { Lasiocroton baha- } \\
\text { mensis Pax \& K. } \\
\text { Hoffm. }\end{array}$ & Wurdack D58 (US) & AY788233 & AY788181 & AY674723 & AY788152 & $\begin{array}{l}\text { OT/T (Adams 1972; } \\
\text { Webster 1994b) }\end{array}$ \\
\hline $\begin{array}{l}\text { Neoscortechinia kin- } \\
\text { gii (Hook. f.) Pax } \\
\text { \& K. Hoffm. }\end{array}$ & Chase $1265(\mathrm{~K})$ & AY788239 & AJ402977 & AY674738 & AY674619 & TRF (Webster 1994b) \\
\hline
\end{tabular}


Table B1 (Continued)

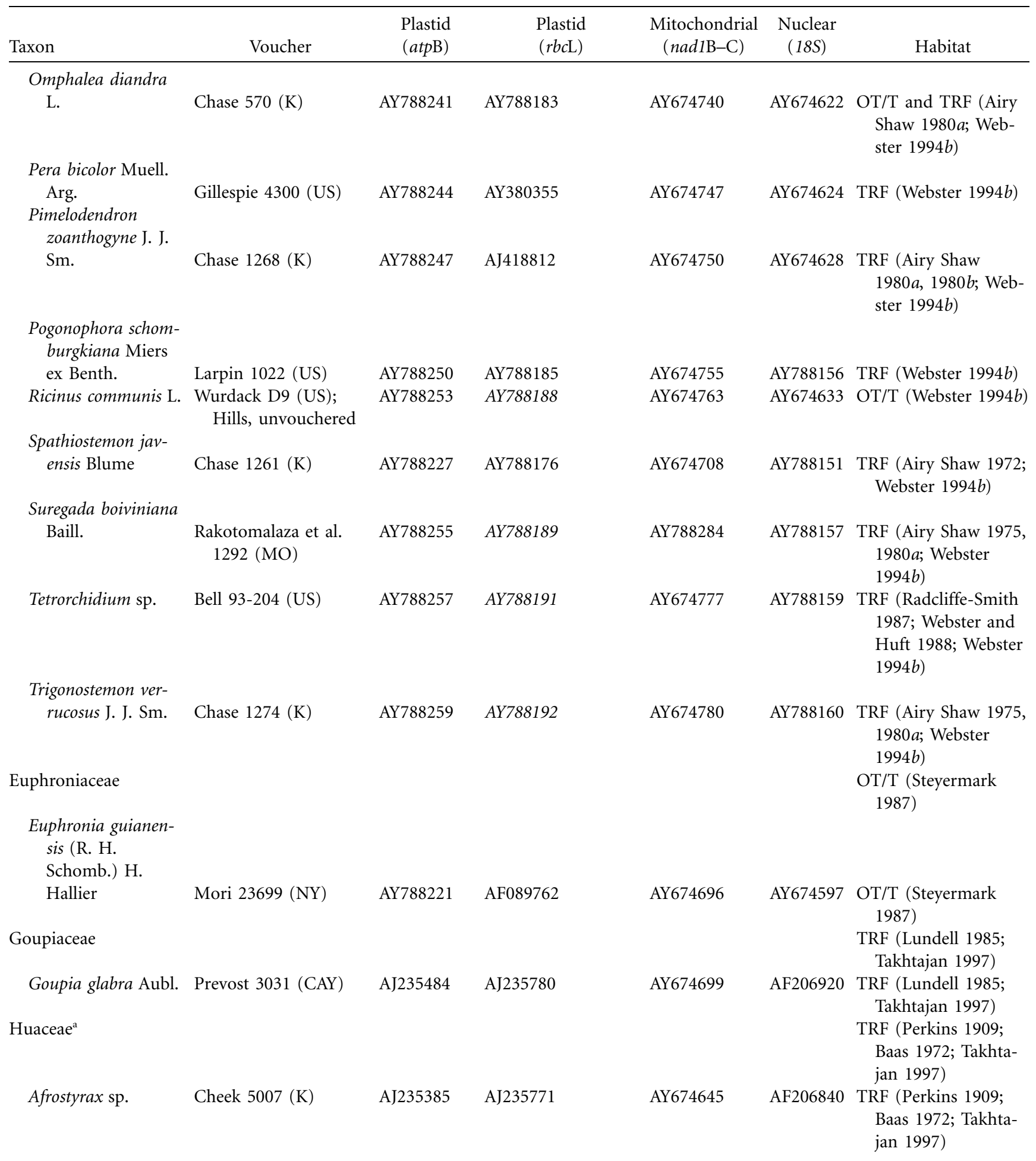


Table B1 (Continued)

\begin{tabular}{|c|c|c|c|c|c|c|}
\hline Taxon & Voucher & $\begin{array}{l}\text { Plastid } \\
(\text { atpB) }\end{array}$ & $\begin{array}{c}\text { Plastid } \\
(r b c \mathrm{~L})\end{array}$ & $\begin{array}{l}\text { Mitochondrial } \\
\quad(\text { nad } 1 \mathrm{~B}-\mathrm{C})\end{array}$ & $\begin{array}{l}\text { Nuclear } \\
(18 S)\end{array}$ & Habitat \\
\hline Humiriaceae & & & & & & $\begin{array}{l}\text { TRF (Cuatrecasas } \\
\text { 1961; Cronquist } \\
\text { 1981) }\end{array}$ \\
\hline Humiria spp. & $\begin{array}{l}\text { Anderson } 13654 \\
\text { (MICH), Wurdack } \\
\text { s.n. (US) }\end{array}$ & AJ235495 & L01926 & AY674710 & AF206930 & $\begin{array}{l}\text { TRF (Cuatrecasas } \\
\text { 1961; Cronquist } \\
\text { 1981) }\end{array}$ \\
\hline \multicolumn{7}{|l|}{ Vantanea guianensis } \\
\hline Aubl. & Pennington $13855(\mathrm{~K})$ & AY788261 & Z75679 & AY674783 & AY674639 & $\begin{array}{l}\text { TRF (Cuatrecasas } \\
\text { 1961; Cronquist } \\
\text { 1981) }\end{array}$ \\
\hline Hypericaceae & & & & & & $\begin{array}{l}\text { OT/T (Hutchinson } \\
\text { 1973; Robson 1974, } \\
\text { 1977, 1981, 1987, } \\
\text { 1990) }\end{array}$ \\
\hline Hypericum spp. & $\begin{array}{c}\text { Chase } 837(\mathrm{~K}) \text {; Wur- } \\
\text { dack D492 (US) }\end{array}$ & AF209602 & AF206779 & AY674715 & AF206934 & $\begin{array}{l}\text { OT/T (Hutchinson } \\
\text { 1973; Robson 1974, } \\
\text { 1977, 1981, 1987, } \\
\text { 1990) }\end{array}$ \\
\hline Vismia spp. & $\begin{array}{l}\text { Miller et al. } 9313 \\
\text { (MO); Gustafsson } \\
302(\mathrm{NY})\end{array}$ & AY788262 & AF518382 & AY674784 & AF674640 & $\begin{array}{l}\text { OT/T (Hutchinson } \\
\text { 1973; Robson 1974) }\end{array}$ \\
\hline $\begin{array}{l}\text { Irvingiaceae } \\
\quad \text { Irvingia malayana }\end{array}$ & & & & & & TRF (Harris 1996) \\
\hline $\begin{array}{l}\text { Oliv. } \\
\text { Klainedoxa gahonen }\end{array}$ & Simpson 2638 (K?) & AF209605 & AF123278 & AY674717 & AF206939 & TRF (Harris 1996) \\
\hline sis Pierre & $\begin{array}{l}\text { Bradley et al. } 1092 \\
\text { (MO) }\end{array}$ & AY788232 & AY663630 & AY674720 & AY674610 & TRF (Harris 1996) \\
\hline $\begin{array}{l}\text { Ixonanthaceae }{ }^{c} \\
\text { Ixonanthes chinensis }\end{array}$ & & & & & & TRF (Kool 1988) \\
\hline $\begin{array}{l}\text { Champ. } \\
\text { Ochthocosmus longi- } \\
\text { pedicellatus Stey- }\end{array}$ & Chen 9812087 (K?) & AY788230 & AY788179 & AY674718 & & TRF (Kool 1988) \\
\hline $\begin{array}{l}\text { erm. \& Luteyn } \\
\text { Lacistemataceae }\end{array}$ & Berry 6561 (MO) & & & & AY674621 & $\begin{array}{l}\text { TRF (Kool 1988) } \\
\text { TRF (Adams 1972; } \\
\text { Sleumer 1980; } \\
\text { Cronquist 1981; } \\
\text { Takhtajan 1997) }\end{array}$ \\
\hline $\begin{array}{l}\text { Lacistema aggrega- } \\
\text { tum Rusby }\end{array}$ & $\begin{array}{l}\text { Pennington et al. } 583 \\
\quad(\mathrm{~K})\end{array}$ & AF206949 & AF206787 & AY674722 & AF206949 & $\begin{array}{l}\text { TRF (Adams 1972; } \\
\text { Sleumer 1980; } \\
\text { Cronquist 1981; } \\
\text { Takhtajan 1997) }\end{array}$ \\
\hline Lepidobotryaceae $^{\mathrm{a}}$ & & & & & & $\begin{array}{l}\text { TRF (Hammel and } \\
\text { Zamora 1993; } \\
\text { Takhtajan 1997) }\end{array}$ \\
\hline $\begin{array}{l}\text { Ruptiliocarpon cara- } \\
\text { colito Hammel \& } \\
\text { Zamora }\end{array}$ & $\begin{array}{l}\text { Pennington \& Zamori } \\
631(\mathrm{~K}) ; \text { Hammel } \\
19102(\mathrm{MO})\end{array}$ & AY788275 & AJ402997 & AY674765 & AY788166 & $\begin{array}{l}\text { TRF (Hammel and } \\
\text { Zamora 1993; } \\
\text { Takhtajan 1997) }\end{array}$ \\
\hline
\end{tabular}


Table B1 (Continued)

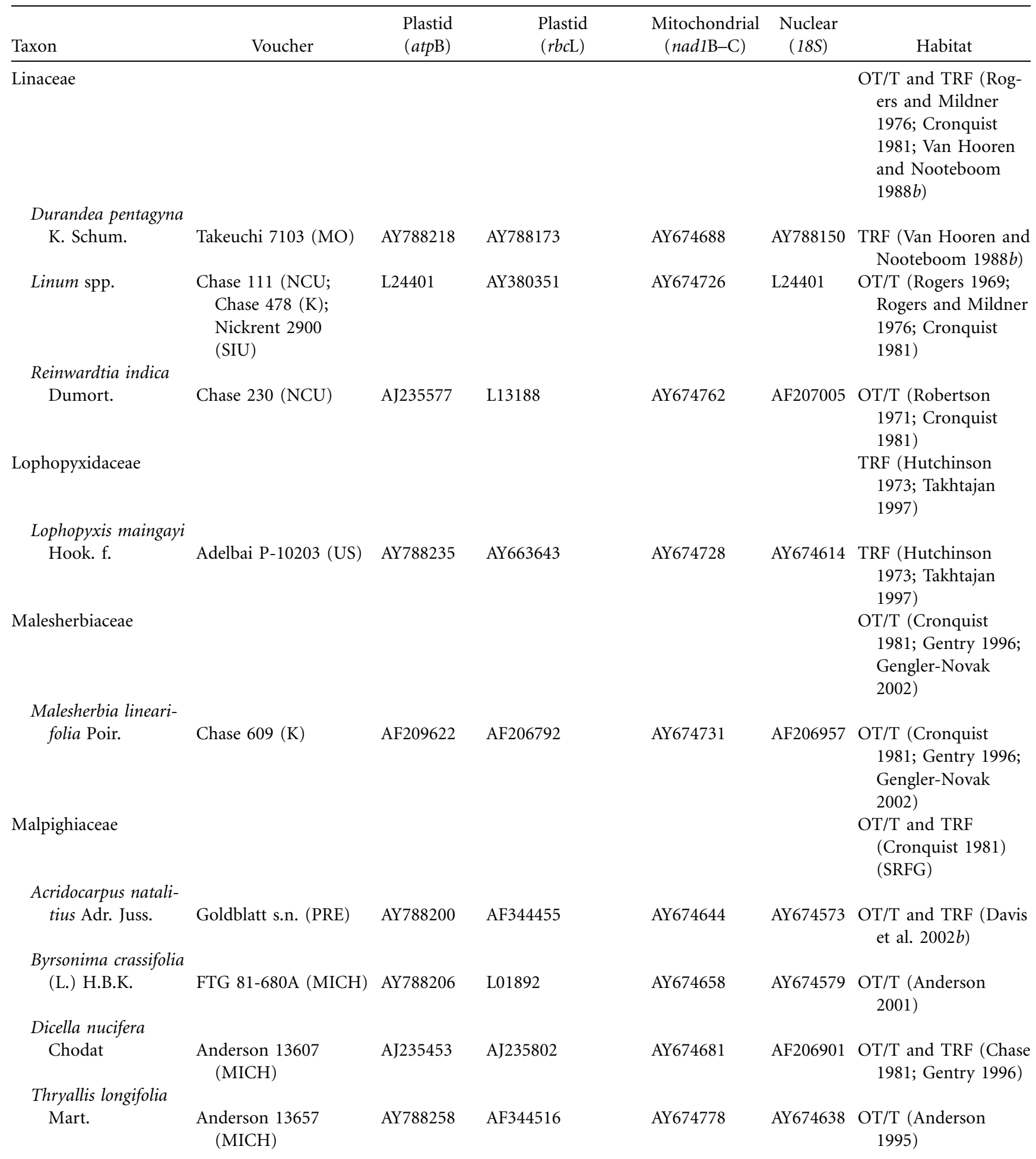


Table B1 (Continued)

\begin{tabular}{|c|c|c|c|c|c|c|}
\hline Taxon & Voucher & $\begin{array}{l}\text { Plastid } \\
(\operatorname{atpB})\end{array}$ & $\begin{array}{c}\text { Plastid } \\
(r b c \mathrm{~L})\end{array}$ & $\begin{array}{l}\text { Mitochondrial } \\
\quad(\text { nad1B-C) }\end{array}$ & $\begin{array}{c}\text { Nuclear } \\
(18 S)\end{array}$ & Habitat \\
\hline Medusagynaceae & & & & & & $\begin{array}{l}\text { TRF (Robinson et al. } \\
\text { 1989; Fay et al. } \\
\text { 1997) }\end{array}$ \\
\hline $\begin{array}{l}\text { Medusagyne opposi- } \\
\quad \text { tifolia Baker }\end{array}$ & $\begin{array}{l}\text { Fay s.n. (K) [Kew } \\
\text { 1981-2059] }\end{array}$ & AJ235530 & $\mathrm{Z} 75670$ & AY674733 & AF206959 & $\begin{array}{l}\text { TRF (Robinson et al. } \\
\text { 1989; Fay et al. } \\
\text { 1997) }\end{array}$ \\
\hline Ochnaceae s.s. ${ }^{b}$ & & & & & & $\begin{array}{l}\text { OT/T and TRF (Kanis } \\
\text { 1968, 1971; Cron- } \\
\text { quist 1981; Amaral } \\
\text { 1991) }\end{array}$ \\
\hline $\begin{array}{l}\text { Cespedesia bonplan- } \\
\quad \text { dii Goudot }\end{array}$ & Chase $1325(\mathrm{~K})$ & AY788208 & AJ420168 & AY674667 & AY674583 & $\begin{array}{l}\text { TRF (Kanis 1971; } \\
\text { Amaral 1991) }\end{array}$ \\
\hline \multicolumn{7}{|l|}{ Ochna multiflora } \\
\hline DC. & Chase 229 (NCU) & AJ235546 & $\mathrm{Z75273}$ & AY788280 & AF206974 & $\begin{array}{l}\text { OT/T and TRF (Kanis } \\
\text { 1968, 1971; Amaral } \\
\text { 1991) }\end{array}$ \\
\hline Ochna sp. & Davis $31-01(\mathrm{~A})$ & AY788240 & AY380354 & AY674739 & AY674620 & $\begin{array}{l}\text { OT/T and TRF (Kanis } \\
\text { 1968, 1971; Amaral } \\
\text { 1991) }\end{array}$ \\
\hline Oxalidaceae $^{\mathrm{a}}$ & & & & & & $\begin{array}{l}\text { OT/T and TRF (Rob- } \\
\quad \text { ertson 1975) }\end{array}$ \\
\hline \multicolumn{7}{|l|}{ Averrhoa carambola } \\
\hline L. & Chase $214(\mathrm{NCU})$ & AJ235404 & L14692 & AY674651 & AF206859 & $\begin{array}{l}\text { TRF (Veldkamp 1971; } \\
\quad \text { Robertson 1975) }\end{array}$ \\
\hline \multicolumn{7}{|l|}{ Dapania racemosa } \\
\hline Korth. & $\begin{array}{l}\text { Ambri \& Arifin } 1014 \\
(\mathrm{~K})\end{array}$ & AY788266 & AY788196 & AY674678 & AY674590 & $\begin{array}{l}\text { TRF (Veldkamp 1967, } \\
\text { 1971; Robertson } \\
\text { 1975) }\end{array}$ \\
\hline Pandaceae & & & & & & $\begin{array}{l}\text { TRF (Forman 1966, } \\
\text { 1971; Airy Shaw } \\
\text { 1975; Cronquist } \\
\text { 1981; Webster } \\
\text { 1994b) }\end{array}$ \\
\hline $\begin{array}{l}\text { Galearia filiformis } \\
\text { (Blume) Boerl. }\end{array}$ & Chase $1334(\mathrm{~K})$ & AY788222 & AJ418818 & AY674698 & AY674598 & $\begin{array}{l}\text { TRF (Forman 1966, } \\
\text { 1971; Airy Shaw } \\
\text { 1975; Webster } \\
\text { 1994b) }\end{array}$ \\
\hline Microdesmis spp. & $\begin{array}{l}\text { Gereau et al. } 5654 \\
\quad(\mathrm{MO}) \text {; Cheek } 5986 \\
\quad(\mathrm{~K})\end{array}$ & AY788238 & AJ402975; AJ403029 & AY674737 & AY674618 & $\begin{array}{l}\text { TRF (Léonard 1961; } \\
\text { Forman 1966; Airy } \\
\text { Shaw 1975; Webster } \\
\text { 1994b) }\end{array}$ \\
\hline Panda oleosa Pierre. & $\begin{array}{l}\text { Schmidt et al. } 2048 \\
\text { (MO) }\end{array}$ & AY788242 & AY663644 & AY788281 & AY788153 & $\begin{array}{l}\text { TRF (Forman 1966, } \\
\text { 1971; Webster } \\
\text { 1994b) }\end{array}$ \\
\hline Passifloraceae s.s. ${ }^{\text {b }}$ & & & & & & $\begin{array}{l}\text { OT/T and TRF (Killip } \\
\text { 1938; Brizicky } \\
\text { 1961 } a \text {; de Wilde } \\
\text { 1971, 1972; Holm- } \\
\text { Nielsen et al. 1988; } \\
\text { MacDougal 1994) }\end{array}$ \\
\hline
\end{tabular}


Table B1 (Continued)

\begin{tabular}{|c|c|c|c|c|c|c|}
\hline Taxon & Voucher & $\begin{array}{l}\text { Plastid } \\
(\text { atp B })\end{array}$ & $\begin{array}{c}\text { Plastid } \\
(r b c \mathrm{~L})\end{array}$ & $\begin{array}{l}\text { Mitochondrial } \\
\text { (nad1B-C) }\end{array}$ & $\begin{array}{c}\text { Nuclear } \\
(18 S)\end{array}$ & Habitat \\
\hline \multicolumn{7}{|l|}{$\begin{array}{l}\text { Paropsia madagas- } \\
\text { cariensis (Baill.) }\end{array}$} \\
\hline H. Perrier & Zyhra 949 (WIS) & AF209645 & AF206802 & AY674744 & AF206980 & $\begin{array}{l}\text { OT/T and TRF (Sleu- } \\
\text { mer 1954; de Wilde } \\
\text { 1975) }\end{array}$ \\
\hline Passiflora spp. & $\begin{array}{l}\text { Chase } 2475(\mathrm{~K}) ; \mathrm{MO} \\
\quad 876630\end{array}$ & AJ235553 & L01940 & AY674745 & AF206981 & $\begin{array}{l}\text { OT/T and TRF (Killip } \\
\text { 1938; Brizicky } \\
\text { 1961 } a \text {; de Wilde } \\
\text { 1972; Holm-Nielsen } \\
\text { et al. 1988; Mac- } \\
\text { Dougal 1994) }\end{array}$ \\
\hline Peridiscaceae $^{\mathrm{a}}$ & & & & & & TRF (Sandwith 1962) \\
\hline \multicolumn{7}{|l|}{ Peridiscus lucidus } \\
\hline Benth. & Soares 205 (CEPEC) & AY372816 & AY380356 & AY674748 & AY372815 & TRF (Sandwith 1962) \\
\hline Phyllanthaceae & & & & & & $\begin{array}{l}\text { OT/T and TRF (Airy } \\
\text { Shaw 1975; Rad- } \\
\text { cliffe-Smith 1987; } \\
\text { Webster 1994b; } \\
\text { Dorr 1999) }\end{array}$ \\
\hline \multicolumn{7}{|l|}{ Aporosa frutescens } \\
\hline Blume & Chase $1251(\mathrm{~K})$ & AY788201 & Z75674 & AY674647 & AY788147 & $\begin{array}{l}\text { TRF (Airy Shaw 1975; } \\
\text { Webster 1994b) }\end{array}$ \\
\hline \multicolumn{7}{|l|}{ Bischofia javanica } \\
\hline Blume & Levin 2200 (SD) & AY788205 & AY663571 & AY674654 & AY674578 & TRF (Webster 1994b) \\
\hline Croizatia spp. & $\begin{array}{l}\text { Berry et al. } 4121 \text { (US); } \\
\text { Dorr \& Yustiz } 8555 \\
\text { (US) }\end{array}$ & AY788213 & AY663579 & AY674674 & AY788148 & $\begin{array}{l}\text { TRF (Webster 1994b; } \\
\text { Dorr 1999) }\end{array}$ \\
\hline \multicolumn{7}{|l|}{ Heywoodia lucens } \\
\hline Sim & $\begin{array}{l}\text { Saufferer et al. } 1544 \\
\text { (US) }\end{array}$ & AY788224 & AY663587 & AY674704 & AY674602 & $\begin{array}{l}\text { OT/T and TRF (Rad- } \\
\text { cliffe-Smith 1987) }\end{array}$ \\
\hline \multicolumn{7}{|l|}{ Phyllanthus epiphyl- } \\
\hline lanthus L. & Wurdack D56 (US) & AY788246 & AY380358 & AY674749 & AY674627 & $\begin{array}{l}\text { OT/T and TRF (Web- } \\
\text { ster 1994b) }\end{array}$ \\
\hline Picrodendraceae & & & & & & $\begin{array}{l}\text { OT/T and TRF (Web- } \\
\text { ster 1994b) }\end{array}$ \\
\hline $\begin{array}{l}\text { Androstachys john- } \\
\text { sonii Prain }\end{array}$ & Chase $1904(\mathrm{~K})$ & AF209527 & AJ402922 & AY674646 & AF206848 & OT/T (Webster 1994b) \\
\hline \multicolumn{7}{|l|}{$\begin{array}{l}\text { Austrobuxus mega- } \\
\text { carpus P. I. }\end{array}$} \\
\hline Forster & Forster 21239 (BRI) & AY788204 & AY380343 & AY788276 & AY674576 & TRF (Webster 1994b) \\
\hline $\begin{array}{l}\text { Micrantheum hex- } \\
\text { andrum Hook. f. }\end{array}$ & Chase $1940(\mathrm{~K})$ & AY788237 & AJ418816 & AY674736 & AY674617 & $\begin{array}{l}\text { TRF (Bentham 1873; } \\
\text { Webster 1994b) }\end{array}$ \\
\hline $\begin{array}{l}\text { Petalostigma pubes- } \\
\text { cens Domin }\end{array}$ & Clifford s.n. (BRI) & AY788245 & AY380357 & AY788283 & AY674626 & $\begin{array}{l}\text { OT/T (Airy Shaw } \\
1980 b)\end{array}$ \\
\hline $\begin{array}{l}\text { Podocalyx loranthoi- } \\
\text { des Klotzsch }\end{array}$ & $\begin{array}{l}\text { Berry \& Aymard } 7226 \\
\quad(\mathrm{MO})\end{array}$ & AY788248 & AY663647 & AY674752 & AY674629 & TRF (Webster 1994b) \\
\hline \multicolumn{7}{|l|}{ Tetracoccus dioicus } \\
\hline Parry & Levin 2202 (DUKE) & AY788256 & AY788190 & AY674774 & AY788158 & OT/T (Webster 1994b) \\
\hline
\end{tabular}


Table B1 (Continued)

\begin{tabular}{|c|c|c|c|c|c|c|}
\hline Taxon & Voucher & $\begin{array}{l}\text { Plastid } \\
(\text { atpB })\end{array}$ & $\begin{array}{c}\text { Plastid } \\
(r b c \mathrm{~L})\end{array}$ & $\begin{array}{l}\text { Mitochondrial } \\
\quad(\text { nad1B-C) }\end{array}$ & $\begin{array}{c}\text { Nuclear } \\
(18 S)\end{array}$ & Habitat \\
\hline Podostemaceae & & & & & & $\begin{array}{l}\text { OT/T (van Royen } \\
\text { 1953, 1954; Graham } \\
\text { and Wood 1975; } \\
\text { Cronquist 1981) }\end{array}$ \\
\hline $\begin{array}{l}\text { Podostemum cerato- } \\
\text { phyllum Michx. }\end{array}$ & $\begin{array}{l}\text { Cusick } 30042 \text { (NY); } \\
\text { Horn \& Wurdack } \\
\text { s.n. (DUKE) }\end{array}$ & AY788249 & AJ418819 & AY674754 & AY788155 & $\begin{array}{l}\text { OT/T (van Royen } \\
\text { 1953, 1954; Graham } \\
\text { and Wood 1975; } \\
\text { Cronquist 1981) }\end{array}$ \\
\hline Putranjivaceae $^{c}$ & & & & & & $\begin{array}{l}\text { TRF (Airy Shaw 1975, } \\
\text { 1980a; Webster } \\
\text { 1994b) }\end{array}$ \\
\hline \multicolumn{7}{|l|}{ Drypetes diversifolia } \\
\hline Krug \& Urb. & Wurdack D57 (US) & & & AY674687 & & $\begin{array}{l}\text { TRF (Airy Shaw 1975, } \\
\text { 1980a; Webster } \\
\text { 1994b) }\end{array}$ \\
\hline $\begin{array}{l}\text { Putranjiva roxbur- } \\
\text { ghii Wall. }\end{array}$ & FTG-83463A & AF209578 & M95757 & & U42534 & $\begin{array}{l}\text { TRF (Airy Shaw 1975, } \\
\text { 1980a; Webster } \\
\text { 1994b) }\end{array}$ \\
\hline Quiinaceae & & & & & & $\begin{array}{l}\text { TRF (Cronquist 1981; } \\
\text { Schneider et al. } \\
\text { 2002) }\end{array}$ \\
\hline $\begin{array}{l}\text { Quiina pteridophylla } \\
\text { (Radlk.) Pires }\end{array}$ & Pires S. A. $(\text { CPATU })^{d}$ & AF209664 & Z75689 & AY674759 & AF207003 & $\begin{array}{l}\text { TRF (Cronquist 1981; } \\
\text { Schneider et al. } \\
\text { 2002) }\end{array}$ \\
\hline Rhizophoraceae s.s. ${ }^{\mathrm{b}}$ & & & & & & $\begin{array}{l}\text { TRF (Cronquist 1981; } \\
\text { Juncosa and Tom- } \\
\text { linson 1988a, } \\
\text { 1988b; Schwarzbach } \\
\text { and Ricklefs 2000) }\end{array}$ \\
\hline $\begin{array}{l}\text { Bruguiera gymnor- } \\
\quad \text { hiza Lam. }\end{array}$ & Chase $12838(\mathrm{~K})$ & AF209547 & AF127693 & AY674656 & AF206875 & $\begin{array}{l}\text { TRF (Cronquist 1981; } \\
\text { Juncosa and Tom- } \\
\text { linson 1988a, } \\
\text { 1988b; Schwarzbach } \\
\text { and Ricklefs 2000) }\end{array}$ \\
\hline $\begin{array}{l}\text { Carallia brachiata } \\
\text { (Lour.) Merr. }\end{array}$ & Chase $2151(\mathrm{~K})$ & AJ235425 & AF206744 & AY674660 & AF530810 & $\begin{array}{l}\text { TRF (Cronquist 1981; } \\
\text { Juncosa and Tom- } \\
\text { linson 1988a, } \\
\text { 1988b; Schwarzbach } \\
\text { and Ricklefs 2000) }\end{array}$ \\
\hline $\begin{array}{l}\text { Paradrypetes subin- } \\
\text { tegrifolia } \mathrm{G} . \mathrm{A} . \\
\text { Levin }^{\mathrm{e}}\end{array}$ & $\begin{array}{l}\text { Acevedo-Rdgz. \& } \\
\text { Cedeño } 7560 \text { (US) }\end{array}$ & AY788243 & AY788184 & AY788282 & AY788154 & $\begin{array}{r}\text { TRF (Levin 1992; } \\
\text { Webster 1994b) }\end{array}$ \\
\hline Salicaceae & & & & & & $\begin{array}{l}\text { OT/T and TRF } \\
\text { (Cronquist 1981) } \\
\text { (SRFG) }\end{array}$ \\
\hline $\begin{array}{c}\text { Abatia parviflora } \\
\text { Ruiz \& Pav. }\end{array}$ & Pennington $676(\mathrm{~K})$ & AF209519 & AF206726 & AY674641 & AF206836 & OT/T (Sleumer 1980) \\
\hline
\end{tabular}


Table B1 (Continued)

\begin{tabular}{|c|c|c|c|c|c|c|}
\hline Taxon & Voucher & $\begin{array}{l}\text { Plastid } \\
(\operatorname{atp} \mathrm{B})\end{array}$ & $\begin{array}{c}\text { Plastid } \\
(r b c \mathrm{~L})\end{array}$ & $\begin{array}{l}\text { Mitochondrial } \\
(\text { nad } 1 \mathrm{~B}-\mathrm{C})\end{array}$ & $\begin{array}{l}\text { Nuclear } \\
(18 S)\end{array}$ & Habitat \\
\hline Casearia spp. & $\begin{array}{l}\text { Chase } 337(\mathrm{~K}) \text {; Litt } 17 \\
\text { (NY); Alford } 26 \\
(\mathrm{BH})\end{array}$ & AF209557 & AF206746 & AY674663 & AF206882 & $\begin{array}{l}\text { OT/T and TRF (Sleu- } \\
\text { mer } 1954,1980)\end{array}$ \\
\hline $\begin{array}{c}\text { Dovyalis rhamnoides } \\
\text { Burch. ex Harv. }\end{array}$ & & & & & & \\
\hline \& Sond. & Chase 271 (NCU) & AY788217 & Z75677 & AY674686 & AY674592 & TRF (Sleumer 1975) \\
\hline \multicolumn{7}{|l|}{ Flacourtia jangomas } \\
\hline Steud. & Chase $2150(\mathrm{~K})$ & AF209588 & AF206768 & AY674697 & AF206912 & $\begin{array}{l}\text { OT/T and TRF (Sleu- } \\
\text { mer } 1954,1975)\end{array}$ \\
\hline \multicolumn{7}{|l|}{ Idesia polycarpa } \\
\hline Maxim. & $\begin{array}{c}\text { Chase } 561(\mathrm{~K}) \text {; Wur- } \\
\text { dack D22 (US) }\end{array}$ & AF209604 & AF206781 & AY674716 & AF206936 & $\begin{array}{l}\text { OT/T (Mabberley } \\
\text { 1997) }\end{array}$ \\
\hline Lunania sp. & Alford 69 (BH) & AY788236 & AY788182 & AY674729 & AY674615 & $\begin{array}{l}\text { OT/T and TRF (Sleu- } \\
\text { mer 1980) }\end{array}$ \\
\hline Poliothyrsis sp. & Alford $44(\mathrm{BH})$ & AY788251 & AY788186 & AY674756 & AY674631 & $\begin{array}{l}\text { OT/T (Mabberly } \\
\text { 1997) }\end{array}$ \\
\hline Populus spp. & $\begin{array}{l}\text { Chase } 996 \text { (K); Soltis } \\
\text { \& Soltis } 2552 \text { (WS) }\end{array}$ & AF209658 & AJ418836 & AY674757 & AF206999 & $\begin{array}{l}\text { OT/T (Cronquist } \\
\text { 1981; Mabberley } \\
\text { 1997) }\end{array}$ \\
\hline Prockia sp. & Alford $85(\mathrm{BH})$ & AY788252 & AY788187 & AY674758 & AY674632 & $\begin{array}{l}\text { OT/T and TRF (Sleu- } \\
\text { mer 1980) }\end{array}$ \\
\hline Salix reticulata L. & Chase $840(\mathrm{~K})$ & AJ235590 & AJ235793 & AY674767 & AF207011 & $\begin{array}{l}\text { OT/T (Cronquist } \\
\text { 1981) }\end{array}$ \\
\hline $\begin{array}{l}\text { Scyphostegia bor- } \\
\text { neensis Stapf }\end{array}$ & Beaman $911(\mathrm{BH})$ & AY788254 & AJ403000 & AY674770 & AY674635 & $\begin{array}{l}\text { TRF (van Steenis } \\
\text { 1957) }\end{array}$ \\
\hline Trigoniaceae & & & & & & TRF (Cronquist 1981) \\
\hline \multicolumn{7}{|l|}{ Trigonia nivea } \\
\hline Cambess. & $\begin{array}{l}\text { Anderson } 13656 \\
(\mathrm{MICH})\end{array}$ & AF209691 & AF089761 & AY674779 & AF207047 & TRF (Cronquist 1981) \\
\hline Turneraceae & & & & & & $\begin{array}{l}\text { OT/T (Lewis 1954; } \\
\text { Brizicky 1961a; } \\
\text { Cronquist 1981; } \\
\text { Arbo 1987, 1995) }\end{array}$ \\
\hline Turnera ulmifolia L. & $\begin{array}{l}\text { Chase } 220 \text { (NCU); } \\
\text { Wurdack s.n. (US) }\end{array}$ & AJ235634 & Z75691 & AY674782 & U42817 & $\begin{array}{l}\text { OT/T (Lewis 1954; } \\
\text { Brizicky 1961a; } \\
\text { Cronquist 1981; } \\
\text { Arbo 1987, 1995) }\end{array}$ \\
\hline Violaceae & & & & & & $\begin{array}{l}\text { OT/T and TRF (Bri- } \\
\text { zicky } 1961 b \text {; Cron- } \\
\text { quist 1981; Hekking } \\
\text { 1988) }\end{array}$ \\
\hline Hybanthus sp. & Alford $89(\mathrm{BH})$ & AY788229 & AY788178 & AY674712 & AY674607 & $\begin{array}{l}\text { OT/T and TRF (Bri- } \\
\text { zicky } 1961 b)\end{array}$ \\
\hline $\begin{array}{l}\text { Hymenanthera al- } \\
\text { pina Oliv. }\end{array}$ & Chase $501(\mathrm{~K})$ & AJ235499 & Z75692 & AY674713 & AF206933 & $\begin{array}{l}\text { OT/T (Brizicky 1961b; } \\
\text { Cronquist 1981; } \\
\text { Hekking 1988) }\end{array}$ \\
\hline \multicolumn{7}{|l|}{ Leonia glycycarpa } \\
\hline Ruiz. \& Pav. & Pennington 13852 (K) & AY788234 & Z75693 & AY674725 & AY674613 & $\begin{array}{l}\text { TRF (Brizicky 1961b; } \\
\text { Cronquist 1981; } \\
\text { Hekking 1988) }\end{array}$ \\
\hline
\end{tabular}


Table B1 (Continued)

\begin{tabular}{|c|c|c|c|c|c|c|}
\hline Taxon & Voucher & $\begin{array}{l}\text { Plastid } \\
(\operatorname{atp} \mathrm{B})\end{array}$ & $\begin{array}{c}\text { Plastid } \\
(r b c \mathrm{~L})\end{array}$ & $\begin{array}{l}\text { Mitochondrial } \\
\text { (nad1B-C) }\end{array}$ & $\begin{array}{l}\text { Nuclear } \\
(18 S)\end{array}$ & Habitat \\
\hline \multicolumn{7}{|l|}{$\begin{array}{l}\text { Incertae sedis } \\
\quad \text { (Centroplacaceae) }\end{array}$} \\
\hline $\begin{array}{l}\text { Centroplacus glauci- } \\
\text { nus Pierre }\end{array}$ & $\begin{array}{l}\text { White } 128 \text {, ser. } 1 \\
\text { (MO) }\end{array}$ & AY788207 & AY663646 & AY788277 & AY674582 & TRF (Webster 1994a) \\
\hline
\end{tabular}

Note: Families follow APG (2003; but see footnoted modifications), and herbarium acronyms follow Holmgren et al. (1990). Primary habitat shown with source in parentheses: $\mathrm{TRF}=$ tropical rain forest; OT/T $=$ open tropical/temperate forest. $\mathrm{SRFG}=$ see references for genera; s.s. $=$ sensu stricto.

a Indicates outgroups.

b Several small segregate families sampled were maintained for the family-level scoring of habitat following the strict circumscriptions of APG (2003). For example, representatives of Chrysobalanaceae, Dichapetalaceae, Euphroniaceae, and Trigoniaceae were scored separately rather than as Chrysobalanceae sensu lato. Other similar strict circumscriptions were followed for Ochnaceae, Passifloraceae, and Rhizophoraceae. Peridiscaceae have been excluded from Malpighiales following Davis and Chase (2004). Recent molecular evidence indicates that holoparasitic Rafflesiaceae s.s. are members of Malpighiales (Barkman et al. 2004; Davis and Wurdack 2004). They were not included in our data sets due to missing data. This is because the genes sampled here are largely unsuited for phylogenetic placement of Rafflesiaceae s.s. due to their reduced chloroplast genome (specifically, the loss of atpB and $r b c \mathrm{~L}$ ) and hypothesized horizontal gene transfer of mitochondrial nad1B-C from their obligate hosts Tetrastigma (Davis and Wurdack 2004).

${ }^{c}$ Both genera are combined as one family OTU for molecular analysis.

d Empresa Brasileira de Pesquisa Agropecuária.

e Newly proposed family affiliation.

\section{Literature Cited in Table B1}

Adams, C. D. 1972. Flowering plants of Jamaica. University of the West Indies, Mona, Jamaica.

Airy Shaw, H. K. 1968. XCVI. New or noteworthy species of Homalanthus Juss. Kew Bulletin 21:409-418.

—. 1972. The Euphorbiaceae of Siam. Kew Bulletin 26:191-363.

- 1975. The Euphorbiaceae of Borneo. Kew Bulletin Additional Series 4:1-245.

_ 1980a. The Euphorbiaceae of New Guinea. Kew Bulletin Additional Series 8:1-243.

. 1980b. A partial synopsis of the Euphorbiaceae-Platylobeae of Australia (excluding Phyllanthus, Euphorbia, and Calycopeplus). Kew Bulletin 35:577-700.

Amaral, M. C. E. 1991. Phylogenetische Systematik der Ochnaceae. Botanische Jahrbücher für Systematik, Pflanzengeschichte und Pflanzengeographie 113:105-196.

Anderson, C. 1995. Revision of Thryallis (Malpighiaceae). Contributions from the University of Michigan Herbarium 20:3-14.

Anderson, W. R. 2001. Malpighiaceae. Flora of the Venezuelan Guyana 6:82-185.

Arbo, M. M. 1987. Turneraceae. Flora del Paraguay 6:1-65. . 1995. Turneraceae. I. Piriqueta. Flora Neotropica Monograph 67:1-156.

Baas, P. 1972. Anatomical contributions to plant taxonomy. II. The affinities of Hua Pierre and Afrostyrax Perkins et Gilg. Blumea 20: 161-192.

Baas, P., R. Geesink, W. A. Van Heel, and J. Muller. 1979. The affinities of Plagiopteron suaveolens Griff. (Plagiopteraceae). Grana 18:6989.

Baker, W. J., M. J. E. Coode, J. Dransfield, S. Dransfield, M. M. Harley, and R. J. Johns. 1998. Patterns of distribution of Malesian vascular plants. Pages 243-258 in R. Hall and J. D. Holloway, eds. Biogeography and geological evolution of SE Asia. Backhuys, Leiden.

Barker, W. R. 1984. Stackhousiaceae. Flora of Australia 22:186-199. Barkman, T. J., S.-K. Lim, K. Mat Salleh, and J. Nais. 2004. Mito- chondrial DNA sequences reveal the photosynthetic relatives of Rafflesia, the world's largest flower. Proceedings of the National Academy of Sciences of the USA 101:787-792.

Bentham, G. 1873. Euphorbiaceae. Flora Australiensis 6:57-58.

Bentham, G., and F. Mueller. 1864. Saxifragaceae. Flora Australiensis 2:435-450.

Blakelock, R. A. 1951. A synopsis of the genus Euonymous L. Kew Bulletin 1951:210-290.

Bradford, J. C. 1998. A cladistic analysis of species groups in Weinmannia (Cunoniaceae) based on morphology and inflorescence architecture. Annals of the Missouri Botanical Garden 85:565-593.

- 2002. Molecular phylogenetic and morphological evolution in Cunonieae (Cunoniaceae). Annals of the Missouri Botanical Garden 89:491-503.

Breteler, F. J. 1991. Dichapetalaceae. Flore du Gabon 32:1-221.

Bricker, J. S. 1991. A revision of the genus Crinodendron (Elaeocarpaceae). Systematic Botany 16:77-88.

Brizicky, G. K. 1961a. The genera of Turneraceae and Passifloraceae in the southeastern United States. Journal of the Arnold Arboretum Harvard University 42:204-218.

- 1961b. The genera of Violaceae in the southeastern United States. Journal of the Arnold Arboretum Harvard University 42: 321-333.

- 1965. The genera of Tiliaceae and Elaeocarpaceae in the southeastern United States. Journal of the Arnold Arboretum Harvard University 46:286-307.

Carlquist, S. 1980. Anatomy and systematics of Balanopaceae. Allertonia 2:191-246.

- 1987. Wood anatomy and relationships of Stackhousiaceae. Botanische Jahrbücher für Systematik, Pflanzengeschichte und Pflanzengeographie 108:473-480.

Chase, M. W. 1981. A revision of Dicella (Malpighiaceae). Systematic Botany 6:159-171.

Coode, M. J. E. 2001. Elaeocarpus for Flora Malesiana: the Coilopetalum group in Sulawesi and Maluku. Kew Bulletin 56:837-874. Cuatrecasas, J. 1961. A taxonomic revision of the Humiriaceae. Contributions from the United States National Herbarium 35:25-214. Davis, C. C., C. D. Bell, P. W. Fritsch, and S. Mathews. 2002b. Phy- 
logeny of Acridocarpus-Brachylophon (Malpighiaceae): implications for Tertiary tropical floras and Afroasian biogeography. Evolution 56:2395-2405.

de la Bathie, H. P. 1946. Célastracées. Flore de Madagascar et des Comores 116:1-76.

. 1952. Érythroxylacées. Flore de Madagascar et des Comores 102:1-52.

Demissew, S. 1985. The genus Maytenus (Celastraceae) in NE tropical Africa and Arabia. Symbolae Botanicae Upsalienses 25:1-101.

de Wilde, W. J. J. O. 1971. A monograph of the genus Adenia Forsk. (Passifloraceae). Veenman, Wageningen.

. 1972. Passifloraceae. Flora Malesiana, ser. 1, Spermatophyta $7: 405-434$.

- 1975. Passifloraceae. Flora of Tropical East Africa. Crown Agents for Oversea Governments, London.

Dorr, L. J. 1999. A new combination in Croizatia (Euphorbiaceae). SIDA Contributions to Botany 18:831-836.

Fay, M. F., S. M. Swensen, and M. W. Chase. 1997. Taxonomic affinities of Medusagyne oppositifolia (Medusagynaceae). Kew Bulletin 52:111-120.

Forman, L. L. 1966. The reinstatement of Galearia Zoll. \& Mor. and Microdesmis Hook. f. in the Pandaceae. Kew Bulletin 20:309-321. 1971. A synopsis of Galearia Zoll. \& Mor. (Pandaceae). Kew Bulletin 26:153-165.

Fosberg, F. R., and S. A. Renvoize. 1980. The flora of Aldabra and neighbouring islands. Kew Bulletin Additional Series 7:1-358.

Gengler-Novak, K. 2002. Reconstruction of the biogeographical history of Malesherbiaceae. Botanical Review 68:171-188.

Gentry, A. H. 1996. A field guide to the families and genera of woody plants of northwest South America (Colombia, Ecuador, Peru): with supplementary notes on herbaceous taxa. University of Chicago Press, Chicago.

Graham, S. A., and C. E. Wood. 1975. The genera of the Podostemaceae in the southeastern United States. Journal of the Arnold Arboretum Harvard University 56:456-465.

Hammel, B. E., and N. A. Zamora. 1993. Ruptiliocarpon (Lepidobotryaceae): a new arborescent genus and tropical American link to Africa, with a reconsideration of the family. Novon 3:408-417.

Harris, B. J. 1996. A revision of the Irvingiaceae in Africa. Bulletin du Jardin Botanique National de Belgique 65:143-196.

Hekking, W. H. A. 1988. Violaceae. I. Rinorea and Rinoreocarpus. Flora Neotropica, Monograph 46:1-208.

Holmgren, P. K., N. H. Holmgren, and L. C. Barnett. 1990. Index herbariorum. 1. The herbaria of the world. New York Botanical Garden, New York.

Holm-Nielsen, L. B., P. M. Jørgensen, and J. E. Lawesson. 1988. 126. Passifloraceae. Flora of Ecuador 31:1-130.

Hoogland, R. D. 1951. Dilleniaceae. Flora Malesiana, ser. 1, Spermatophyta 4:141-164.

1952. A revision of the genus Dillenia. Blumea 7:1-145.

. 1979. Studies in the Cunoniaceae. II. The genera Caldcluvia,

Pullea, Acsmithia, and Spiraeanthemum. Blumea 25:481-505.

- 1981. Studies in the Cunoniaceae. III. Additional notes on Ceratopetalum and Acrophyllum. Brunonia 4:213-216.

Hou, D. 1955. A revision of the genus Celastrus. Annals of the Missouri Botanical Garden 42:215-302.

1962. Celastraceae. I. Flora Malesiana, ser. 1, Spermatophyta 6:227-291.

- 1964. Celastraceae. II. Flora Malesiana, ser. 1, Spermatophyta 6:389-421.
Hutchinson, J. 1973. The families of flowering plants arranged according to a new system based on their probable phylogeny. Clarendon, Oxford.

Jessup, L. W. 1984. Celastraceae. Flora of Australia 22:150-180.

Juncosa, A. M., and P. B. Tomlinson. 1988a. A historical and taxonomic synopsis of Rhizophoraceae and Anisophyllaceae. Annals of the Missouri Botanical Garden 75:1278-1295.

- 1988b. Systematic comparison and some biological characteristics of Rhizophoraceae and Anisophylleaceae. Annals of the Missouri Botanical Garden 75:1296-1318.

Kanis, A. 1968. A revision of the Ochnaceae of the Indo-Pacific area. Blumea 16:1-82.

- 1971. Ochnaceae. Flora Malesiana, ser. 1, Spermatophyta 7: 97-119.

Killip, E. P. 1938. The American species of Passifloraceae. Publications of the Field Museum of Natural History, Chicago.

Kool, R. 1988. Ixonanthaceae. Flora Malesiana, ser. 1, Spermatophyta 10:621-627.

Kubitzki, K. 1978. The botany of the Guyana Highland. X. Caraipa and Mahurea (Bonnetiaceae). Memoirs of the New York Botanical Garden 29:82-128.

Leach, G. J. 1989. Taxonomic revision of Bergia (Elatinaceae) in Australia. Journal of the Adelaide Botanic Gardens 11:75-100.

Léonard, J. 1961. Noutulae systematicae. XXXI. Révision des especès Africaines de Microdesmis (Euphorbiacèes). Bulletin du Jardin Botanique National de Belgique 31:159-197.

Levin, G. A. 1992. Systematics of Paradrypetes (Euphorbiaceae). Systematic Botany 17:74-83.

Lewis, J. 1954. Turneraceae: Flora of Tropical East Africa. Crown Agents for the Colonies, London.

Lowrie, A. 1998. Carnivorous plants of Australia. Vol. 3. University of Western Australia Press, Nedlands.

Lundell, C. L. 1985. Goupia guatemalensis (Celastraceae): a genus and species new to Mesoamerica. Phytologia 57:238-239.

Ma, J. S., A. R. Brach, and Q. R. Liu. 1999. A revision of the genus Tripterygium (Celastraceae). Edinburgh Journal of Botany 56:3346.

Mabberley, D. J. 1997. The plant-book. Cambridge University Press, Cambridge.

MacDougal, J. M. 1994. Revision of Passiflora subgenus Decaloba section Pseudodysosmia (Passifloraceae). Systematic Botany Monographs 41:1-146.

Maguire, B. 1972. The botany of the Guayana Highland. IX. Memoirs of the New York Botanical Garden 23:1-832.

Murillo, J. 2000. Novedades en la tribu Alchorneae (Euphorbiaceae). Revista de la Academia Colombiana de Ciencias Exactas, Físicas y Naturales 24:359-370.

Navaro, A. M., and W. H. Blackwell. 1990. A revision of Paxistima (Celastraceae). SIDA Contributions to Botany 14:231-249.

Payens, J. P. D. W. 1958. Erythroxylaceae. Flora Malesiana, ser. 1, Spermatophyta 54:543-552.

Perkins, J. 1909. Eine neue Gattung der Styracaceae aus dem tropischen Afrika. Botanische Jahrbücher für Systematik, Pflanzengeschichte und Pflanzengeographie 43:214-217.

Plowman, T. 1989. 93. Erythroxylaceae. Flora of Ecuador 36:1-32.

Plowman, T., and P. E. Berry. 1999. Erythroxylaceae. Flora of the Venezuelan Guyana 5:59-71.

Prance, G. T. 1970. The genera of Chrysobalanaceae in the southeastern United States. Journal of the Arnold Arboretum Harvard University 51:521-528. 
1972a. Chrysobalanaceae. Flora Neotropica, no. 9. Hafner, New York.

1972b. Dichapetalaceae. Flora Neotropica, no. 10. Hafner, New York.

1973. Phytogeographic support for the theory of Pleistocene forest refuges in the Amazon Basin, based on evidence from distribution patterns in Caryocaraceae, Chrysobalanaceae, Dichapetalaceae, and Lecythidaceae. Acta Amazonica 3:5-28.

—. 1989b. Chrysobalanaceae. Flora Malesiana, ser. 1, Spermatophyta 10:635-678.

Prance, G. T., and M. Freitas da Silva. 1973. Caryocaraceae. Flora Neotropica, no. 12. Hafner, New York.

Radcliffe-Smith. A. 1987. Euphorbiaceae. I. Flora of Tropical East Africa. Crown Agents for the Colonies, London.

Robertson, K. R. 1971. The Linaceae in the southeastern United States. Journal of the Arnold Arboretum Harvard University 52: 649-665.

1975. The Oxalidaceae in the southeastern United States. Journal of the Arnold Arboretum Harvard University 56:223-239.

Robinson, A., R. Wise, and F. White. 1989. Medusagyne oppositifolia. Medusagynaceae. Kew Magazine 6:166-171.

Robson, N. K. B. 1974. Hypericaceae. Flora Malesiana, ser. 1, Spermatophyta 8:1-29.

. 1977. Studies in the genus Hypericum L. (Guttiferae). I. Infrageneric classification. Bulletin of the British Museum (Natural History) Botany 5:293-355.

- 1981. Studies in the genus Hypericum L. (Guttiferae). II. Characters of the genus. Bulletin of the British Museum (Natural History) Botany 8:55-226.

. 1987. Studies in the genus Hypericum L. (Guttiferae). VII. Section 29. Brathys (part 1). Bulletin of the British Museum (Natural History) Botany 16:1-106.

. 1990. Studies in the genus Hypericum L. (Guttiferae). VIII. Section 29. Brathys (part 2) and 30. Trigynobrathys. Bulletin of the British Museum (Natural History) Botany 20:1-151.

Rogers, C. M. 1969. Relationships of the North American species of Linum (flax). Bulletin of the Torrey Botanical Club 96:176-190.

Rogers, C. M., and R. A. Mildner. 1976. South American Linum: a summary. Rhodora 78:761-766.

Sandwith, N. Y. 1962. Contribution to the flora of tropical America. LXIX. A new genus of Peridiscaceae. Kew Bulletin 16:467-471.

Schneider, J. V., U. Swenson, and G. Zizka. 2002. Phylogenetic reconstruction of the Neotropical family Quiinaceae (Malpighiales) based on morphology with remarks on the evolution of an androdioecious sex distribution. Annals of the Missouri Botanical Garden 89:64-76.

Schultes, R. E. 1990. A brief taxonomic view of the genus Hevea. Malaysian Rubber Research and Development Board Monograph 14:1-57.

Schwarzbach, A. E., and R. E. Ricklefs. 2000. Systematic affinities of Rhizophoraceae and Anisophylleaceae, and intergeneric relationships within Rhizophoraceae, based on chloroplast DNA, nuclear ribosomal DNA, and morphology. American Journal of Botany 87:547-564.

Sleumer, H. O. 1938. Monographie der Gattung Hydnocarpus Gaertner. Botanische Jahrbücher für Systematik, Pflanzengeschichte und Pflanzengeographie 69:1-94.

- 1954. Flacourtiaceae. Flora Malesiana, ser. 1, Spermatophyta $5: 13-106$

1975. Flacourtiaceae. Flora of Tropical East Africa. Crown Agents for Oversea Governments, London.

. 1980. Flacourtiaceae. Flora Neotropica, no. 22. Hafner, New York.

Smith, A. C. 1944. Studies of Papuasian plants. Journal of the Arnold Arboretum 25:270-298.

Smith, C. E. 1954. The New World species of Sloanea (Elaeocarpaceae). Contributions from the Gray Herbarium of Harvard University $175: 1-114$.

Standley, P. C., and J. A. Steyermark. 1949. Flora of Guatemala. IV. Annals of the Missouri Botanical Garden 54:1-440.

Steyermark, J. A. 1987. Flora of the Venezuelan Guyana. II. Annals of the Missouri Botanical Garden 74:85-116.

Takhtajan, A. 1997. Diversity and classification of flowering plants. Columbia University Press, New York.

Tucker, G. C. 1986. The genera of Elatinaceae in the southeastern United States. Journal of the Arnold Arboretum Harvard University $67: 471-483$.

Van Hooren, A. M. N., and H. P. Nooteboom. 1988a. Ctenolophonaceae. Flora Malesiana, ser. 1, Spermatophyta 10:629-634.

- 1988b. Linaceae. Flora Malesiana, ser. 1, Spermatophyta 10: $607-620$.

van Royen, P. 1953. The Podostemaceae of the New World. II. Acta Botanica Neerlandica 2:1-21.

. 1954. The Podostemaceae of the New World. III. Acta Botanica Neerlandica 3:215-263.

van Steenis, C. G. G. J. 1957. Scyphostegiaceae. Flora Malesiana, ser. 1, Spermatophyta 5:297-299.

Veldkamp, J. F. 1967. A revision of Sarcotheca Bl. and Dapania Korth. (Oxalidaceae). Blumea 15:519-599.

. 1971. Oxalidaceae. Flora Malesiana, ser. 1, Spermatophyta 7:151-178.

Verdcourt, B. 1984. Erythroxylaceae. Flora of Tropical East Africa. Balkema, Rotterdam.

Webster, G. L. 1993. A provisional synopsis of the sections of the genus Croton (Euphorbiaceae). Taxon 42:793-823.

- 1994a. Classification of the Euphorbiaceae. Annals of the Missouri Botanical Garden 81:3-32.

- 1994b. Synopsis of the genera and suprageneric taxa of Euphorbiaceae. Annals of the Missouri Botanical Garden 81:33-144.

Webster, G. L., and W. S. Armbruster. 1991. A synopsis of the Neotropical species of Dalechampia (Euphorbiaceae). Botanical Journal of the Linnean Society 105:137-177.

Webster, G. L., and M. J. Huft. 1988. Revised synopsis of Panamanian Euphorbiaceae. Annals of the Missouri Botanical Garden 75:10871144. 


\section{APPENDIX C}

Table C1: Clade age estimates

\begin{tabular}{|c|c|c|c|c|c|c|}
\hline \multirow[b]{2}{*}{ Clade name } & \multicolumn{3}{|c|}{ Maximum age constraint $125 \mathrm{Ma}$} & \multicolumn{3}{|c|}{ Maximum age constraint $109 \mathrm{Ma}$} \\
\hline & Minimum & Optimal & Maximum & Minimum & Optimal & Maximum \\
\hline 1. Malpighiales & 110.7 & 113.8 & 119.4 & 101.1 & 101.6 & 105.9 \\
\hline 2. Euphorbiaceae & 110.7 & 113.8 & 119.4 & 101.1 & 101.6 & 105.9 \\
\hline 3. Rhizophoraceae s.l. & 110.2 & 113.8 & 119.3 & 102.1 & 101.6 & 105.7 \\
\hline 4. Pandaceae & 110.2 & 113.8 & 118.7 & 101.9 & 101.6 & 105.5 \\
\hline 5. Caryocaraceae & 108.5 & 112.3 & 117.6 & 99.5 & 100.7 & 103.8 \\
\hline 6. Humiriaceae & 108.9 & 112.2 & 117.2 & 100.3 & 101.6 & 102.8 \\
\hline 7. Ochnaceae s.l. & 108.2 & 111.2 & 116.6 & 98.8 & 99.6 & 103.8 \\
\hline 8. Ixonanthaceae & 105.9 & 109.2 & 114.9 & 97.5 & 98.7 & 102.0 \\
\hline 9. Phyllanthaceae & 105.8 & 108.1 & 114.0 & 95.6 & 97.1 & 101.9 \\
\hline 10. Picrodendraceae & 105.8 & 108.1 & 114.0 & 95.6 & 97.1 & 101.9 \\
\hline 11. Passifloraceae s.l. & 103.7 & 108.1 & 113.9 & 96.5 & 96.9 & 102.1 \\
\hline 12. Violaceae & 102.4 & 105.7 & 112.3 & 94.4 & 94.8 & 99.7 \\
\hline 13. Irvingiaceae & 102.5 & 105.0 & 112.5 & 93.3 & 94.5 & 98.4 \\
\hline 14. Linaceae & 102.5 & 105.0 & 112.5 & 93.3 & 94.5 & 98.4 \\
\hline 15. Achariaceae & 98.1 & 104.2 & 108.1 & 90.9 & 93.4 & 96.1 \\
\hline 16. Goupiaceae & 98.1 & 104.2 & 108.1 & 90.9 & 93.4 & 96.1 \\
\hline 17. Centroplacus & 96.6 & 101.8 & 109.6 & 88.1 & 91.0 & 97.1 \\
\hline 18. Ctenolophonaceae & 96.6 & 101.8 & 109.6 & 88.1 & 91.0 & 97.1 \\
\hline 19. Lacistemataceae & 96.1 & 99.8 & 107.7 & 89.0 & 90.1 & 95.9 \\
\hline 20. Salicaceae & 96.1 & 99.8 & 107.7 & 89.0 & 90.1 & 95.9 \\
\hline 21. Balanopaceae & 95.5 & 99.6 & 106.2 & 88.5 & 90.2 & 94.9 \\
\hline 22. Chrysobalanceae s.l. & 95.5 & 99.6 & 106.2 & 88.5 & 90.2 & 94.9 \\
\hline 23. Elatinaceae & 89.0 & 98.2 & 113.2 & 85.0 & 89.1 & 99.6 \\
\hline 24. Malpighiaceae & 89.0 & 98.2 & 113.2 & 85.0 & 89.1 & 99.6 \\
\hline 25. Clusiaceae & 92.4 & 94.1 & 103.7 & 87.1 & 89.0 & 94.7 \\
\hline 26. Bonnetiaceae & 85.9 & 88.5 & 97.2 & 83.0 & 83.8 & 88.3 \\
\hline 27. Lophopyxidaceae & 82.9 & 86.7 & 97.0 & 74.8 & 77.8 & 85.2 \\
\hline 28. Putranjivaceae & 82.9 & 86.7 & 97.0 & 74.8 & 77.8 & 85.2 \\
\hline 29. Hypericaceae & 68.9 & 76.4 & 82.4 & 66.4 & 72.4 & 73.9 \\
\hline 30. Podostemaceae & 68.9 & 76.4 & 82.4 & 66.4 & 72.4 & 73.9 \\
\hline
\end{tabular}

Note: Optimal age estimates, with minimum and maximum error estimates, for major Malpighiales clades (i.e., families [stem group], except for Centroplacus). Sensu lato (s.l.) designations follow APG (2003). See figure C1 for full penalized likelihood chronogram and figure C2 for Bayesian tree with likelihood branch lengths. 


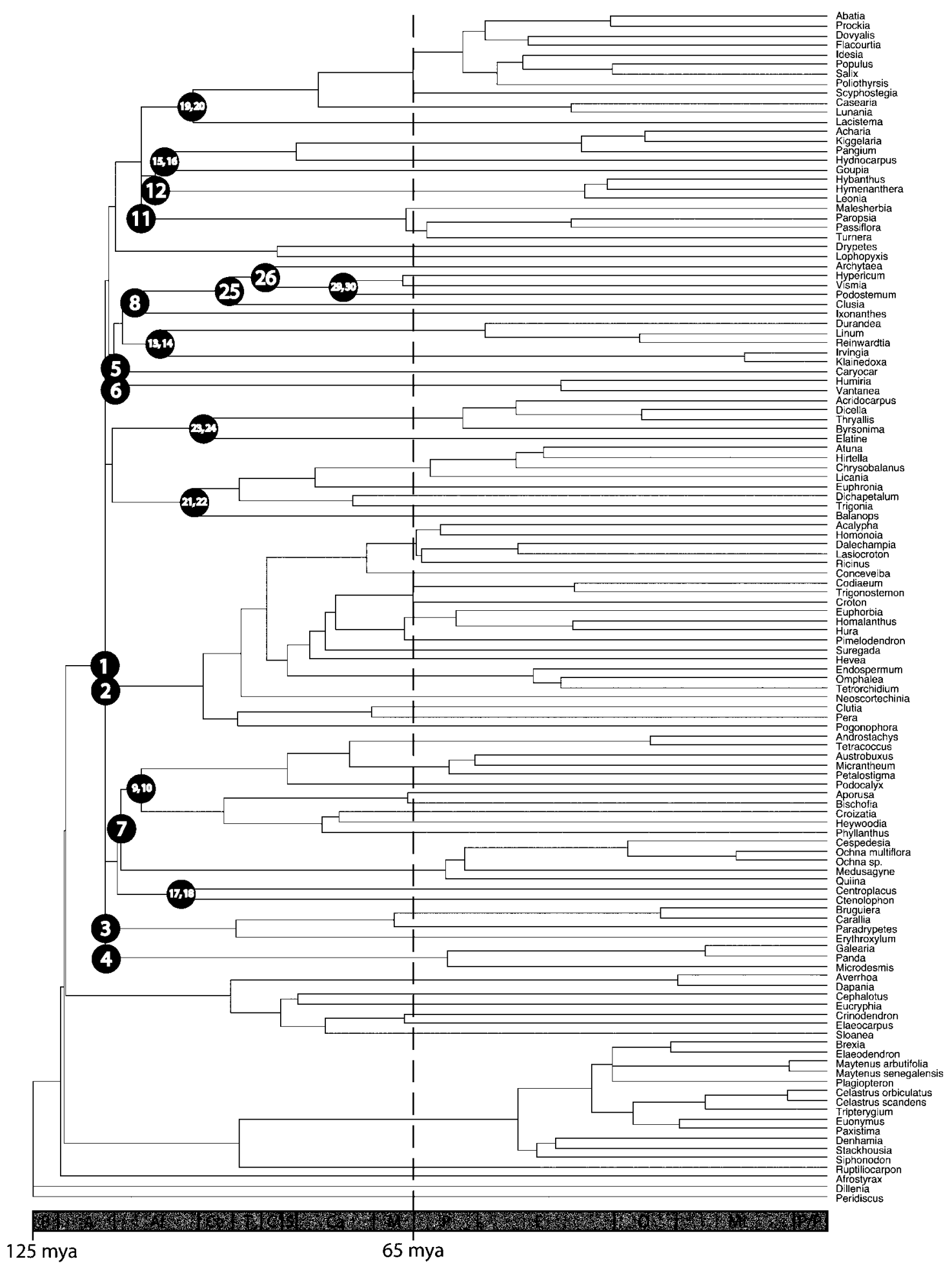

Figure C1: Complete 124-taxon penalized likelihood chronogram (from main text, fig. 1). Numbered nodes on chronogram correspond to numbered clades shown in table C1. The K/T boundary $(\sim 65 \mathrm{Ma})$ is marked with a dashed line. The scale bar indicates major Cretaceous and Cenozoic intervals: $B=$ Barremian, $A=$ Aptian, $A l=$ Albian, $C e=$ Cenomanian, $T=$ Turonian, $C=$ Coniacian, $S=$ Santonian, $C a=$ Campanian, $M=$ Maastrichtian, $P=$ Paleocene, $E=$ Eocene, $O=$ Oligocene, $M i=$ Miocene, $P / P=$ Pliocene/Pleistocene. 


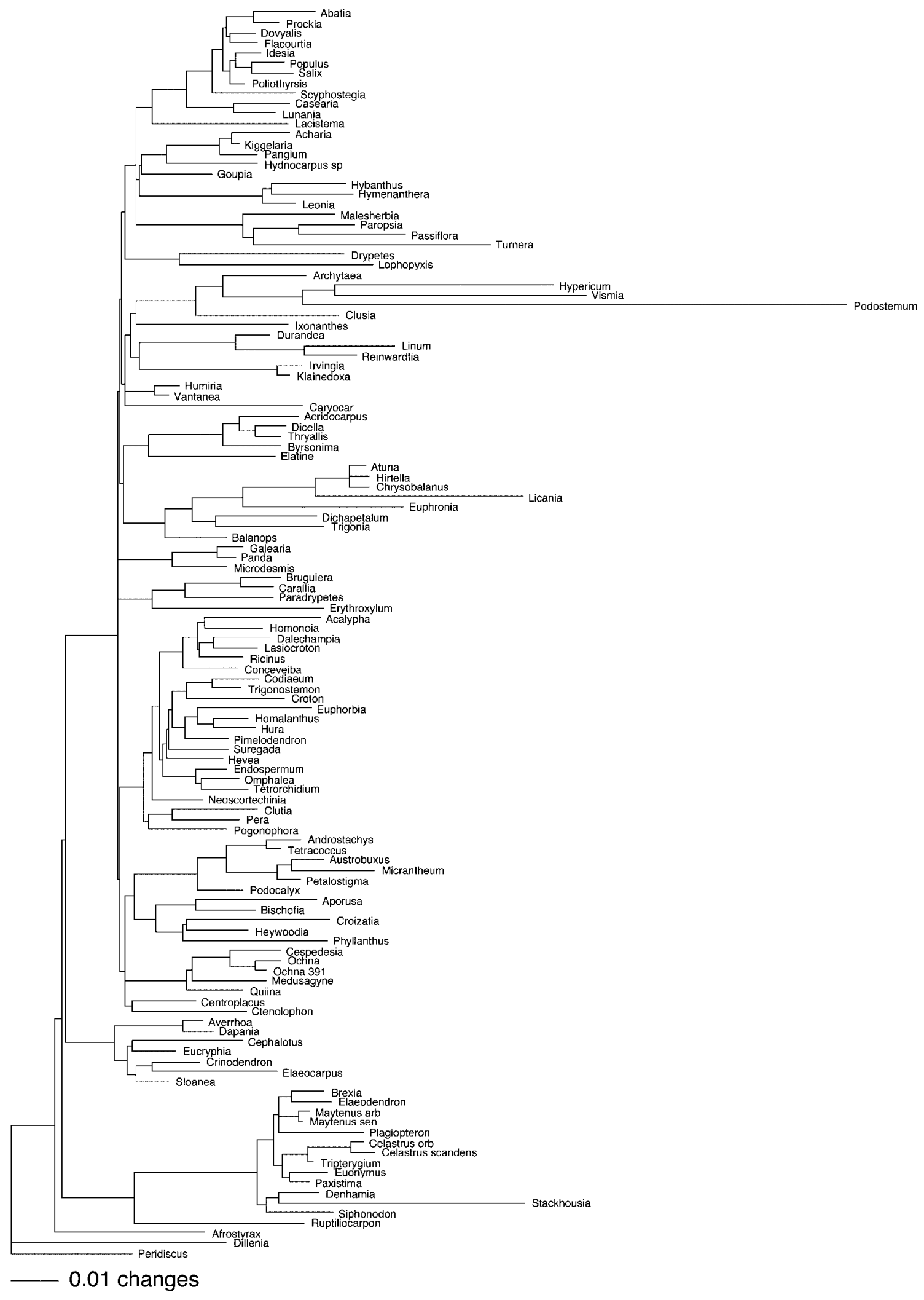

Figure C2: Complete 124-taxon Bayesian tree with likelihood branch lengths used for r8s analysis 


\section{Literature Cited}

Anderberg, A. A., C. Rydin, and M. Källersjö. 2002. Phylogenetic relationships in the order Ericales s.l.: analyses of molecular data from five genes from the plastid and mitochondrial genomes. American Journal of Botany 89:677-687.

APG (Angiosperm Phylogeny Group). 2003. An update of the Angiosperm Phylogeny Group classification for the orders and families of flowering plants: APG II. Botanical Journal of the Linnean Society 141:399-436.

Barron, E. J., and W. M. Washington. 1985. Warm Cretaceous climates: high atmospheric $\mathrm{CO}_{2}$ as a plausible mechanism. Pages 546-553 in E. T. Sundquist and W. S. Broecker, eds. The carbon cycle and atmospheric $\mathrm{CO}_{2}$ : natural variations, Archaean to present. Geophysical Monograph Series. American Geophysical Union, Washington, DC.

Barron, E. J., W. M. Hay, and S. Thompson. 1989. The hydrologic cycle: a major variable during earth history. Palaeogeography, $\mathrm{Pa}-$ laeoclimatology, Palaeoecology 75:157-174.

Beerling, D. J., and F. I. Woodward. 2001, Vegetation and the terrestrial carbon cycle: modelling the first 400 million years. Cambridge University Press, Cambridge.

Behrensmeyer, A. K., J. D. Damuth, W. A. Dimichele, H.-D. Sues, and S. L. Wing. 1992. Terrestrial ecosystems through time: evolutionary paleoecology of terrestrial plants and animals. University of Chicago Press, Chicago.

Berggren, W. A., D. V. Kent, C. C. Swisher II, and M. P. Aubry. 1995. A revised Cenozoic geochronology and chronostratigraphy. Pages 129-212 in W. A. Berggren, D. V. Kent, M. P. Aubry, and J. Hardenbol, eds. Geochronology, time scales and global stratigraphic correlation. SEPM, Tulsa, OK.

Bremer, B., K. Bremer, N. Heidari, P. Erixon, R. G. Olmstead, A. A. Anderberg, M. Källersjö, et al. 2002. Phylogenetics of asterids based on 3 coding and 3 non-coding chloroplast DNA markers and the utility of non-coding DNA at higher taxonomic levels. Molecular Phylogenetics and Evolution 24:274-301.

Burnham, R. J., and A. Graham. 1999. The history of Neotropical vegetation: new developments and status. Annals of the Missouri Botanical Garden 86:546-589.

Cantrill, D. J., and I. Poole. 2005. Taxonomic turnover and abundance in Cretaceous to Tertiary wood floras of Antarctica: implications for change in forest ecology. Palaeogeography, Palaeoclimatology, Palaeoecology 215:205-219.

Chase, M. W., S. Zmarzty, M. D. Lledó, K. J. Wurdack, S. M. Swensen, and M. F. Fay. 2002. When in doubt, put it in Flacourtiaceae: a molecular phylogenetic analysis based on plastid $r b c L$ DNA sequences. Kew Bulletin 57:141-181.

Chesters, K. I. M. 1955. Some plant remains from the upper Cretaceous and Tertiary of West Africa. Annals and Magazine of Natural History 8:498-504.

Crane, P. R. 1987. Vegetational consequences of the angiosperm diversification. Pages 107-144 in E. M. Friis, W. G. Chaloner, and P. R. Crane, eds. The origins of angiosperms and their biological consequences. Cambridge University Press, Cambridge.

Crepet, W. L., and K. C. Nixon. 1998. Fossil Clusiaceae from the Late Cretaceous (Turonian) of New Jersey and implications regarding the history of bee pollination. American Journal of Botany 85:1122-1133.

Cronquist, A. 1981. An integrated system of classification of flowering plants. Columbia University Press, New York.
Davis, C. C., and M. W. Chase. 2004. Elatinaceae are sister to Malpighiaceae; Peridiscaceae belong to Saxifragales. American Journal of Botany 91:262-273.

Davis, C. C., and K. J. Wurdack. 2004. Host-to-parasite gene transfer in flowering plants: phylogenetic evidence from Malpighiales. Science 305:676-678.

Davis, C. C., C. D. Bell, S. Mathews, and M. J. Donoghue. $2002 a$. Laurasian migration explains Gondwanan disjunctions: evidence from Malpighiaceae. Proceedings of the National Academy of Sciences of the USA 99:6833-6837.

Doyle, J. A., and E. I. Robbins. 1977. Angiosperm pollen zonation of the continental Cretaceous of the Atlantic Coastal Plain and its application to deep wells in the Salisbury Embayment. Palynology 1:43-78.

Feild, T. S., N. C. Arens, J. A. Doyle, T. E. Dawson, and M. J. Donoghue. 2004. Dark and disturbed: a new image of early angiosperm ecology. Paleobiology 30:82-107.

Felsenstein, J. 1981. Evolutionary trees from DNA sequences: a maximum likelihood approach. Journal of Molecular Evolution 17: 368-376.

- 1985. Confidence limits on phylogenies: an approach using the bootstrap. Evolution 39:783-791.

Gentry, A. H. 1982. Neotropical floristic diversity: phytogeographical connections between Central and South America, Pleistocene climatic fluctuations, or an accident of the Andean orogeny? Annals of the Missouri Botanical Garden 69:557-593.

Gradstein, F. M., F. R. Agterberg, J. G. Ogg, J. Hardenbol, P. van Veen, J. Thierry, and Z. Huang. 1995. A Triassic, Jurassic and Cretaceous time scale. Pages 95-126 in W. A. Berggren, D. V. Kent, M. P. Aubry, and J. Hardenbol, eds. Geochronology, time scales and global stratigraphic correlation. SEPM (Society for Sedimentary Geology), Tulsa, OK.

Grime, J. P. 1979. Plant strategies and vegetation processes. Wiley, Chichester.

Grubb, P. J. 1996. Rainforest dynamics: the need for new paradigms. Pages 215-233 in D. S. Edwards, W. E. Booth, and S. C. Choy, eds. Tropical rainforest research: current issues. Kluwer, Dordrecht.

- 1998. Seeds and fruits of tropical rainforest plants: interpretation of the range in seed size, degree of defense, and flesh/ seed quotients. Pages 1-24 in D. M. Newbery, H. H. T. Prins, and N. D. Brown, eds. Dynamics of tropical communities. Blackwell, Oxford.

Grubb, P. J., and D. J. Metcalfe. 1996. Adaptation and inertia in the Australian tropical lowland rain-forest flora: contradictory trends in intergeneric and intrageneric comparisons of seed size in relation to light demand. Functional Ecology 10:512-520.

Hall, J. S. 2003. The role of habitat specialization in the regeneration of Entandophragma spp.: implications for the maintenance of species diversity and forest management in Central Africa. PhD diss. Yale University, New Haven, CT.

Hall, R. 1998. The plate tectonics of Cenozoic SE Asia and the distribution of land and sea. Pages 99-131 in R. Hall and J. D. Holloway, eds. Biogeography and geological evolution of SE Asia. Backhuys, Leiden.

Hoot, S. B., A. Culham, and P. R. Crane. 1995. The utility of atpB gene sequences in resolving phylogenetic relationships: comparison with $r b c L$ and $18 \mathrm{~S}$ ribosomal DNA sequences in the Lardizabalaceae. Annals of the Missouri Botanical Garden 82:194-207.

Huelsenbeck, J. P., and B. Rannala. 1997. Phylogenetic methods come 


\section{E64 The American Naturalist}

of age: testing hypotheses in an evolutionary context. Science 276: 227-232.

Huelsenbeck, J. P., and F. Ronquist. 2001. MRBAYES: Bayesian inference of phylogenetic trees. Bioinformatics 17:754-755.

Jaramillo, C. A. 2002. Response of tropical vegetation to Paleogene warming. Paleobiology 28:222-243.

Johnson, K. R., and B. Ellis. 2002. A tropical rainforest in Colorado 1.4 million years after the Cretaceous-Tertiary boundary. Science 296:2379-2383.

Lewis, P. O. 2001. A likelihood approach to estimating phylogeny from discrete morphological character data. Systematic Biology 50: 913-925.

Maddison, D. R. 1994. Phylogenetic methods for inferring the evolutionary history and processes of change in discretely valued characters. Annual Review of Entomology 39:267-292.

Maddison, W. P., and D. R. Maddison. 2003. Mesquite: a modular system for evolutionary analysis, version 1.0. http:// mesquiteproject.org/mesquite/mesquite.html

Magallón, S., P. R. Crane, and P. S. Herendeen. 1999. Phylogenetic pattern, diversity, and diversification of eudicots. Annals of the Missouri Botanical Garden 86:297-372.

Morley, R. J. 2000. Origin and evolution of tropical rain forests. Wiley, Chichester.

Muller, J. 1981. Fossil pollen records of extant angiosperms. Botanical Review 47:1-142.

Otto-Bliesner, B. L., and G. R. Upchurch. 1997. Vegetation-induced warming of high latitudes during the latest Cretaceous. Nature 385:804-807.

Pitman, N. C. A., J. Terborgh, M. R. Silman, P. Núñez V., D. A. Neill, C. E. Cerón, W. A. Palacios, et al. 2001. Dominance and distribution of tree species in upper Amazonian terra firme forests. Ecology 82:2101-2117.

Posada, D., and K. A. Crandall. 1998. MODELTEST: testing the model of DNA substitution. Bioinformatics 14:817-818.

Prance, G. T. 1982. Biological diversification in the tropics. Columbia University Press, New York.

1989a. American tropical forests. Pages 99-132 in H. Lieth and M. J. A. Werger, eds. Tropical rain forest ecosystems. Elsevier, Amsterdam.

Rambaut, A., and N. C. Grassly. 1997. Seq-Gen: an application for the Monte Carlo simulation of DNA sequence evolution along phylogenetic trees. Computer Applications in the Biosciences 13: 235-238.

Ree, R. H., and M. J. Donoghue. 1998. Step matrices and the interpretation of homoplasy. Systematic Biology 47:582-588.

Reeves, G., M. W. Chase, P. Goldblatt, P. Rudall, M. F. Fay, A. V. Cox, B. Lejeune, et al. 2001. Molecular systematics of Iridaceae: evidence from four plastid DNA regions. American Journal of Botany 88:2074-2087.

Richards, P. W. 1996. The tropical rain forest: an ecological study. Cambridge University Press, Cambridge.

Richardson, J. E., R. T. Pennington, T. D. Pennington, and P. M. Hollingsworth. 2001. Rapid diversification of a species-rich genus of Neotropical rain forest trees. Science 293:2242-2245.

Sanderson, M. J. 2002. Estimating absolute rates of molecular evolution and divergence times: a penalized likelihood approach. Molecular Biology and Evolution 19:101-109.

2003. r8s: inferring absolute rates of molecular evolution and divergence times in the absence of a molecular clock. Bioinformatics 19:301-302.
Sanderson, M. J., and J. A. Doyle. 2001. Sources of error and confidence intervals in estimating the age of angiosperms from $r b c L$ and $18 \mathrm{~S}$ rDNA data. American Journal of Botany 88:1499-1516.

Schneider, H., E. Schuettpelz, K. M. Pryer, R. Cranfill, S. Magallón, and R. Lupia. 2004. Ferns diversified in the shadow of angiosperms. Nature 428:553-557.

Soltis, D. E., and P. S. Soltis. 1997. Phylogenetic relationships in Saxifragaceae sensu lato: a comparison of topologies based on $18 \mathrm{~S}$ rDNA and $r b c L$ sequences. American Journal of Botany 84:504522.

Soltis, D. E., A. E. Senters, M. J. Zanis, S. Kim, J. D. Thompson, P. S. Soltis, L. P. Ronse Decraene, et al. 2003. Gunnerales are sister to other core eudicots: implications for the evolution of pentamery. American Journal of Botany 90:461-470.

Stevens, P. F. 2003. Angiosperm phylogeny Web site. http:// www.mobot.org/MOBOT/research/APweb.

Swofford, D. L. 2003. PAUP*: phylogenetic analysis using parsimony ( ${ }^{*}$ and other methods). Version 4. Sinauer, Sunderland, MA.

Thorne, R. F. 2002. How many species of seed plants are there? Taxon 51:511-512.

Tiffney, B. H. 1984. Seed size, dispersal syndromes, and the rise of the angiosperms: evidence and hypothesis. Annals of the Missouri Botanical Garden 71:551-576.

. 1985a. The Eocene North Atlantic land bridge: its importance in Tertiary and modern phytogeography of the Northern Hemisphere. Journal of the Arnold Arboretum Harvard University 66:243-273.

- $1985 b$. Perspectives on the origin of the floristic similarity between eastern Asia and eastern North America. Journal of the Arnold Arboretum Harvard University 66:73-94.

Upchurch, G. R., and J. A. Wolfe. 1987. Mid-Cretaceous to Early Tertiary vegetation and climate: evidence from fossil leaves and wood. Pages 75-105 in E. M. Friis, W. G. Chaloner, and P. R. Crane, eds. The origins of angiosperms and their biological consequences. Cambridge University Press, Cambridge.

-1993. Cretaceous vegetation of the western interior and adjacent regions of North America. Pages 243-281 in E. G. Kauffman and W. G. E. Caldwell, eds. Cretaceous Evolution of the western interior basin. Geological Association of Canda, Special Paper, vol. 39.

Upchurch, G. R., B. L. Otto-Bliesner, and C. Scotese. 1998. Vegetation-atmosphere interactions and their role in global warming during the latest Cretaceous. Philosophical Transactions of the Royal Society of London B 353:97-112.

Webb, C. O. 1997. Seedling ecology and tree diversity in a Bornean rain forest. PhD diss. Dartmouth College, Dartmouth, NH.

Webb, C. O., and D. R. Peart. 2000. Habitat associations of trees and seedlings in a Bornean rain forest. Journal of Ecology 88:464-478.

Webb, C. O., D. D. Ackerly, M. A. McPeek, and M. J. Donoghue. 2002. Phylogenies and community ecology. Annual Review of Ecology and Systematics 33:475-505.

Wheeler, E. A., and P. Baas. 1991. A survey of the fossil record for dicotyledonous wood and its significance for evolutionary and ecological wood anatomy. IAWA Bulletin 12:275-332.

White, F. 1983. Vegetation of Africa: a descriptive memoir to accompany the UNESCO/AETFAT/UNSO vegetation map of Africa. UNESCO, Paris.

Whitmore, T. C. 1998. An introduction to tropical rain forests. Oxford University Press, Oxford.

Whitmore, T. C., and G. T. Prance. 1987. Biogeography and Qua- 
ternary history in tropical America. Oxford University Press, New York.

Whitten, W. M., N. H. Williams, and M. W. Chase. 2000. Subtribal and generic relationships of Maxillarieae (Orchidaceae) with emphasis on Stanhopeinae: combined molecular evidence. American Journal of Botany 87:1842-1856.

Wikström, N., V. Savolainen, and M. W. Chase. 2001. Evolution of the angiosperms: calibrating the family tree. Proceedings of the Royal Society of London B 268:2211-2220.

Wing, S. L., and L. D. Boucher. 1998. Ecological aspects of the Cretaceous flowering plant radiation. Annual Review of Earth and Planetary Sciences 26:379-421.

Wing, S. L., and B. H. Tiffney. 1987. Interactions of angiosperms and herbivorous tetrapods through time. Pages 203-224 in E. M. Friis, W. G. Chaloner, and P. R. Crane, eds. The origins of angio- sperms and their biological consequences. Cambridge University Press, Cambridge.

Wolfe, J. A. 1978. A paleobotanical interpretation of Tertiary climates in the Northern Hemisphere. American Scientist 66:694-703.

Wolfe, J. A., and G. R. Upchurch. 1987. North American nonmarine climates and vegetation during the Late Cretaceous. Palaeogeography, Palaeoclimatology, Palaeoecology 61:33-77.

Zachos, J., M. Pagani, L. Sloan, E. Thomas, and K. Billups. 2001. Trends, rhythms, and aberrations in global climate $65 \mathrm{Ma}$ to present. Science 292:686-693.

Ziegler, A. M., G. Eshel, P. McAllister Rees, T. A. Rothfus, and D. B. Rowley. 2003. Tracing the Tropics across land and sea: Permian to present. Lethaia $36: 227-254$.

Editor: Jonathan B. Losos Associate Editor: Susanne S. Renner 